\title{
Dinuclear dialkoxo-bridged cyclopentadienylsiloxo titanium complexes $\uparrow$
}

\author{
Lorena Postigo, Javier Sánchez-Nieves, Pascual Royo* and Marta E. G. Mosquerał
}

\author{
Received 10th November 2008, Accepted 18th February 2009 \\ First published as an Advance Article on the web 18th March 2009 \\ DOI: $10.1039 / \mathbf{b 8 2 0 0 9 2 k}$
}

The dinuclear dialkoxo-bridged complexes $\left[(\mathrm{TiCl})_{2}\left(\mu-\mathrm{O}_{2} \mathrm{~L}\right)\left(\mu-\left\{\left(\eta^{5}-\mathrm{C}_{5} \mathrm{Me}_{4} \mathrm{SiMeO}\right)_{2}(\mu-\mathrm{O})\right\}\right)\right]\left(\mathrm{O}_{2} \mathrm{~L}=\right.$ 1,2- $-\mathrm{O}_{2} \mathrm{C}_{2} \mathrm{H}_{4}$ 1a, 1,2- $\left.\mathrm{O}_{2} \mathrm{C}_{6} \mathrm{H}_{4} \mathbf{1 b}, 1,2-\left(\mathrm{OCH}_{2}\right)_{2} \mathrm{C}_{6} \mathrm{H}_{4} \mathbf{1 c}, \mathrm{O}_{2} \mathrm{SiPh}_{2} \mathbf{1 d}\right)$ were obtained by reaction of $\left[\left(\mathrm{TiCl}_{2}\right)_{2}\left(\mu-\left\{\left(\eta^{5}-\mathrm{C}_{5} \mathrm{Me}_{4} \mathrm{SiMeO}\right)_{2}(\mu-\mathrm{O})\right\}\right)\right]$ (A) with the corresponding dilithium salt (1a) or diol (1b, 1c, 1d). Alkylation of $\mathbf{1 a}$ and $\mathbf{1 b}$ with $\mathrm{ClRMg}$ afforded [(TiR $\left.)_{2}\left(\mu-\mathrm{O}_{2} \mathrm{~L}\right)\left(\mu-\left\{\left(\eta^{5}-\mathrm{C}_{5} \mathrm{Me}_{4} \mathrm{SiMeO}\right)_{2}(\mu-\mathrm{O})\right\}\right)\right]$ $\left(\mathrm{O}_{2} \mathrm{~L}=1,2-\mathrm{O}_{2} \mathrm{C}_{2} \mathrm{H}_{4}, \mathrm{R}=\mathrm{Me} \mathbf{2 a}, \mathrm{Bz} \mathbf{3 a} ; \mathrm{O}_{2} \mathrm{~L}=1,2-\mathrm{O}_{2} \mathrm{C}_{6} \mathrm{H}_{4}, \mathrm{R}=\mathrm{Me} \mathbf{2 b}, \mathrm{Bz} \mathbf{3 b}\right)$. Addition of four equiv. of $\mathrm{LiO} i \mathrm{Pr}$ to $\mathbf{A}$ afforded $\left[\left\{\mathrm{Ti}(\mathrm{O} i \mathrm{Pr})_{2}\right\}_{2}\left(\mu-\left\{\left(\eta^{5}-\mathrm{C}_{5} \mathrm{Me}_{4} \mathrm{SiMeO}\right)_{2}(\mu-\mathrm{O})\right\}\right)\right]$ (4). Reaction of 1a with $\mathrm{Al}\left(\mathrm{C}_{6} \mathrm{~F}_{5}\right)_{3}$ produced the elimination of the dialkoxo ligand to give $\left[\left\{\mathrm{TiCl}\left(\mathrm{C}_{6} \mathrm{~F}_{5}\right)\right\}_{2}\left(\mu-\left\{\left(\eta^{5}-\mathrm{C}_{5} \mathrm{Me}_{4}-\right.\right.\right.\right.$ $\left.\left.\left.\mathrm{SiMeO})_{2}(\mu-\mathrm{O})\right\}\right)\right](\mathbf{5})$, whereas the same reaction of $\mathbf{1 b}$ with $\mathrm{Al}\left(\mathrm{C}_{6} \mathrm{~F}_{5}\right)_{3}$ produced the oxo-alane adduct $\left[(\mathrm{TiCl})_{2}\left(\mu-\mathrm{O}_{2} \mathrm{~L}\right)\left(\mu-\left\{\left(\eta^{5}-\mathrm{C}_{5} \mathrm{Me}_{4} \mathrm{SiMeO}\right)_{2}\left(\mu-\mathrm{O} \cdot \mathrm{Al}\left\{\mathrm{C}_{6} \mathrm{~F}_{5}\right\}_{3}\right)\right\}\right)\right]\left(\mathrm{O}_{2} \mathrm{~L}=1,2-\mathrm{O}_{2} \mathrm{C}_{6} \mathrm{H}_{4} 6\right)$ which was further transformed to give a mixture of 5 and $\left[(\mathrm{TiCl})\left\{\mathrm{Ti}\left(\mathrm{C}_{6} \mathrm{~F}_{5}\right)\right\}\left(\mu-\mathrm{O}_{2} \mathrm{~L}\right)\left(\mu-\left\{\left(\eta^{5}-\mathrm{C}_{5} \mathrm{Me}_{4} \mathrm{SiMeO}\right)_{2}(\mu-\mathrm{O})\right\}\right)\right]$ $\left(\mathrm{O}_{2} \mathrm{~L}=1,2-\mathrm{O}_{2} \mathrm{C}_{6} \mathrm{H}_{4} 7\right)$. One benzyl group of complexes 3 was abstracted with $\mathrm{E}\left(\mathrm{C}_{6} \mathrm{~F}_{5}\right)_{3}(\mathrm{E}=\mathrm{B}, \mathrm{Al})$ to give the monoionic compounds $\left[\mathrm{Ti}(\mathrm{TiBz})\left(\mu-\mathrm{O}_{2} \mathrm{~L}\right)\left(\mu-\left\{\left(\eta^{5}-\mathrm{C}_{5} \mathrm{Me}_{4} \mathrm{SiMeO}\right)_{2}(\mu-\mathrm{O})\right\}\right)\right]\left[\mathrm{BzE}\left(\mathrm{C}_{6} \mathrm{~F}_{5}\right)_{3}\right]\left(\mathrm{O}_{2} \mathrm{~L}=\right.$ 1,2- $\mathrm{O}_{2} \mathrm{C}_{2} \mathrm{H}_{4}, \mathrm{E}=\mathrm{B} \mathbf{8 B}, \mathrm{Al}$ 8Al; $\mathrm{O}_{2} \mathrm{~L}=1,2-\mathrm{O}_{2} \mathrm{C}_{6} \mathrm{H}_{4}, \mathrm{E}=\mathrm{B}$ 9B), although 8Al was unstable in $\mathrm{CD}_{2} \mathrm{Cl}_{2}$ evolving to a mixture of compounds where $\left[(\mathrm{TiBz})_{2}(\mu-\mathrm{Cl})\left(\mu-\left\{\left(\eta^{5}-\mathrm{C}_{5} \mathrm{Me}_{4} \mathrm{SiMeO}\right)_{2}(\mu-\mathrm{O})\right\}\right)\right]\left[\mathrm{BzAl}\left(\mathrm{C}_{6} \mathrm{~F}_{5}\right)_{3}\right]$ (10) was identified, and compound $\mathbf{9 B}$ was also unstable at ambient temperature. Polymerization of $\varepsilon$-caprolactone was only achieved with the tetraalkoxo compound $\mathbf{4}$. All of these complexes were characterized by NMR spectroscopy and 1a, $\mathbf{1 b}$ and $\mathbf{7}$ by X-ray diffraction studies.

\section{Introduction}

The design of ligands to generate bimetallic systems has been developed with the aim of finding reactivity patterns different from those observed for similar monometallic complexes. ${ }^{1}$ In this regard, olefin polymerization and copolymerization processes with group 4 dinuclear complexes have provided modified final products with respect to those obtained using mononuclear derivatives. ${ }^{2-14}$

Alkoxo, aryloxo and related ligands stabilize high oxidation metal complexes and chelating diol derivatives are adequate ligands for generating bimetallic systems. Furthermore, modifications of the oxygen substituents may also affect the M-O interaction. ${ }^{1,15}$ However, the alkoxo group is not only an ancillary ligand, but also plays an important role in the activation of cyclic esters such as caprolactone and lactide. ${ }^{16-23}$

Our interest in studying functionalized cyclopentadienyl compounds with $\mathrm{SiClMe}_{2}$ moieties, ${ }^{24-32}$ moved our research group to synthesize bimetallic cyclopentadienyl disiloxane derivatives with $\mathrm{Si}-\mathrm{O}-\mathrm{Si}$ bridges for $\mathrm{Nb},{ }^{25,31,33} \mathrm{Mo}^{30}$ and $\mathrm{W}^{30}$ and with $\mathrm{Si}-\mathrm{O}-\mathrm{M}$ bridges for group 4 metals ${ }^{26,32,34}$ and $\mathrm{Nb}^{25,33}$ by hydrolysis of the $\mathrm{Si}-\mathrm{Cl}$ bonds or $\mathrm{CO}_{2}$ insertion into $\mathrm{Si}-\mathrm{N}$ bonds. Conversely, hydrolysis of the functionalized cyclopentadienyl titanium compound $\left[\mathrm{Ti}\left\{\eta^{5}-\mathrm{C}_{5} \mathrm{Me}_{4}\left(\mathrm{SiMeCl}_{2}\right)\right\} \mathrm{Cl}_{3}\right]^{35}$ with a $\mathrm{SiCl}_{2} \mathrm{Me}$ moiety gave the dititanium derivative $\left[\left(\mathrm{TiCl}_{2}\right)_{2}\left(\mu-\left\{\left(\eta^{5}-\mathrm{C}_{5} \mathrm{Me}_{4} \mathrm{SiMeO}\right)_{2}(\mu-\mathrm{O})\right\}\right)\right](\mathbf{A}$, Fig. 1) with both $\mathrm{Si}-\mathrm{O}-\mathrm{Si}$ and $\mathrm{Si}-\mathrm{O}-\mathrm{Ti}$ bridges. ${ }^{36}$ Complex $\mathbf{A}$

Departamento de Química Inorgánica, Universidad de Alcalá, Campus Universitario, E-28871, Alcalá de Henares, Madrid, Spain. E-mail: pascual. royo@uah.es; Fax: +34918854683

$\uparrow$ CCDC reference numbers 708809-708811. For crystallographic data in CIF or other electronic format see DOI: $10.1039 / \mathrm{b} 820092 \mathrm{k}$

† X-Ray diffraction studies.

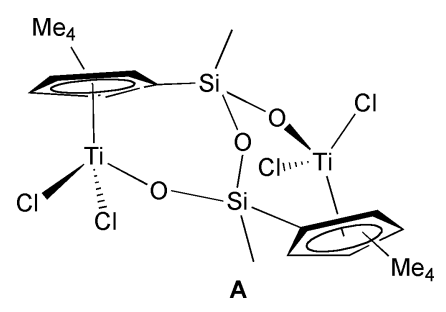

Fig. 1 Compound $\mathbf{A}$.

presented two stereogenic $\mathrm{Si}$ atoms although formation of the $\mathrm{Si}-\mathrm{O}-\mathrm{Si}$ bridge required the reaction to be regioselective and only one diastereoisomer of $\mathrm{C}_{2}$ symmetry was obtained.

Whereas these types of dinuclear complexes have two potentially active metal centres for olefin polymerization, reactions of the titanium complexes $\left[\left(\mathrm{TiBz}_{2}\right)_{2}\left(\mu-\left\{\eta^{5}-\mathrm{C}_{5} \mathrm{Me}_{4} \mathrm{SiMe}_{2} \mathrm{O}\right\}_{2}\right)\right]$ and $\left[\left(\mathrm{TiBz}_{2}\right)_{2}\left(\mu-\left\{\left(\eta^{5}-\mathrm{C}_{5} \mathrm{Me}_{4} \mathrm{SiMeO}\right)_{2}(\mu-\mathrm{O})\right\}\right)\right]$ with Lewis acids formed benzyl bridges between the $\mathrm{Ti}$ atoms, which react further in halogenated solvents providing halogen bridges. ${ }^{36,37}$ The ease of formation of bridges caused complex $\mathbf{A}$ to be inactive in ethylene polymerization, although the methyl derivative $\left[\left(\mathrm{TiMe}_{2}\right)_{2}\left(\mu-\left\{\left(\eta^{5}-\right.\right.\right.\right.$ $\left.\left.\mathrm{C}_{5} \mathrm{Me}_{4} \mathrm{SiMeO}_{2}(\mu-\mathrm{O})\right\}\right)$ ] was active in MMA polymerization. ${ }^{36}$ Abstraction of two alkyl groups was only possible in the reaction of complex $\left[\left(\mathrm{TiBz}_{2}\right)_{2}\left(\mu-\left\{\left(\eta^{5}-\mathrm{C}_{5} \mathrm{Me}_{4} \mathrm{SiMeO}\right)_{2}(\mu-\mathrm{O})\right\}\right)\right]$ with excess $\mathrm{B}\left(\mathrm{C}_{6} \mathrm{~F}_{5}\right)_{3}$ for several days, although the transformation was not complete.

In view of these results and with the aim of generating dicationic dititanium compounds, we report in this paper the synthesis of dialkoxo-bridged dinuclear titanium compounds from complex A. Alkylation reactions of the new complexes, their reactivity toward Lewis acids and finally their activity for polymerization of $\varepsilon$-caprolactone are also presented. 


\section{Results and discussion}

\section{Synthesis of dialkoxo-bridged compounds}

The dinuclear disiloxane complex $\left[\left(\mathrm{TiCl}_{2}\right)_{2}\left(\mu-\left\{\left(\eta^{5}-\mathrm{C}_{5} \mathrm{Me}_{4}-\right.\right.\right.\right.$ $\left.\left.\left.\mathrm{SiMeO})_{2}(\mu-\mathrm{O})\right\}\right)\right](\mathbf{A})$ reacted with the lithium salt $\mathrm{Li}_{2}\left(\mathrm{OCH}_{2}\right)_{2}$ and the free diol compounds $(\mathrm{HO})_{2} \mathrm{~L}\left[(\mathrm{HO})_{2} \mathrm{~L}=1,2-(\mathrm{HO})_{2} \mathrm{C}_{6} \mathrm{H}_{4}, 1,2-\right.$ $\left.\left(\mathrm{HOCH}_{2}\right)_{2} \mathrm{C}_{6} \mathrm{H}_{4},(\mathrm{HO})_{2} \mathrm{SiPh}_{2}\right]$, in the presence of $\mathrm{NEt}_{3}$, in toluene to give the dialkoxo-bridged compounds $\left[(\mathrm{TiCl})_{2}\left(\mu-\mathrm{O}_{2} \mathrm{~L}\right)\left(\mu-\left\{\left(\eta^{5}-\right.\right.\right.\right.$ $\left.\left.\left.\left.\mathrm{C}_{5} \mathrm{Me}_{4} \mathrm{SiMeO}\right)_{2}(\mu-\mathrm{O})\right\}\right)\right]\left(\mathrm{O}_{2} \mathrm{~L}=\mathrm{OCH}_{2} \mathrm{CH}_{2} \mathrm{O} \mathbf{1 a}, 1,2-\mathrm{O}_{2} \mathrm{C}_{6} \mathrm{H}_{4} \mathbf{1 b}\right.$, 1,2-( $\left(\mathrm{OCH}_{2}\right)_{2} \mathrm{C}_{6} \mathrm{H}_{4} \mathbf{1 c}, \mathrm{O}_{2} \mathrm{SiPh}_{2}$ 1d) $(\mathrm{Scheme} 1)$. The resulting yields of these reactions and the stability of these compounds were dependent on the bridge length. Thus, the four-atom bridged compounds $\mathbf{1 a}$ and $\mathbf{1 b}$ were obtained in good yield and were stable at room temperature, whereas the six-atom and three-atom bridged derivatives 1c and 1d were respectively obtained in low and rather poor yield, and were also more air sensitive.

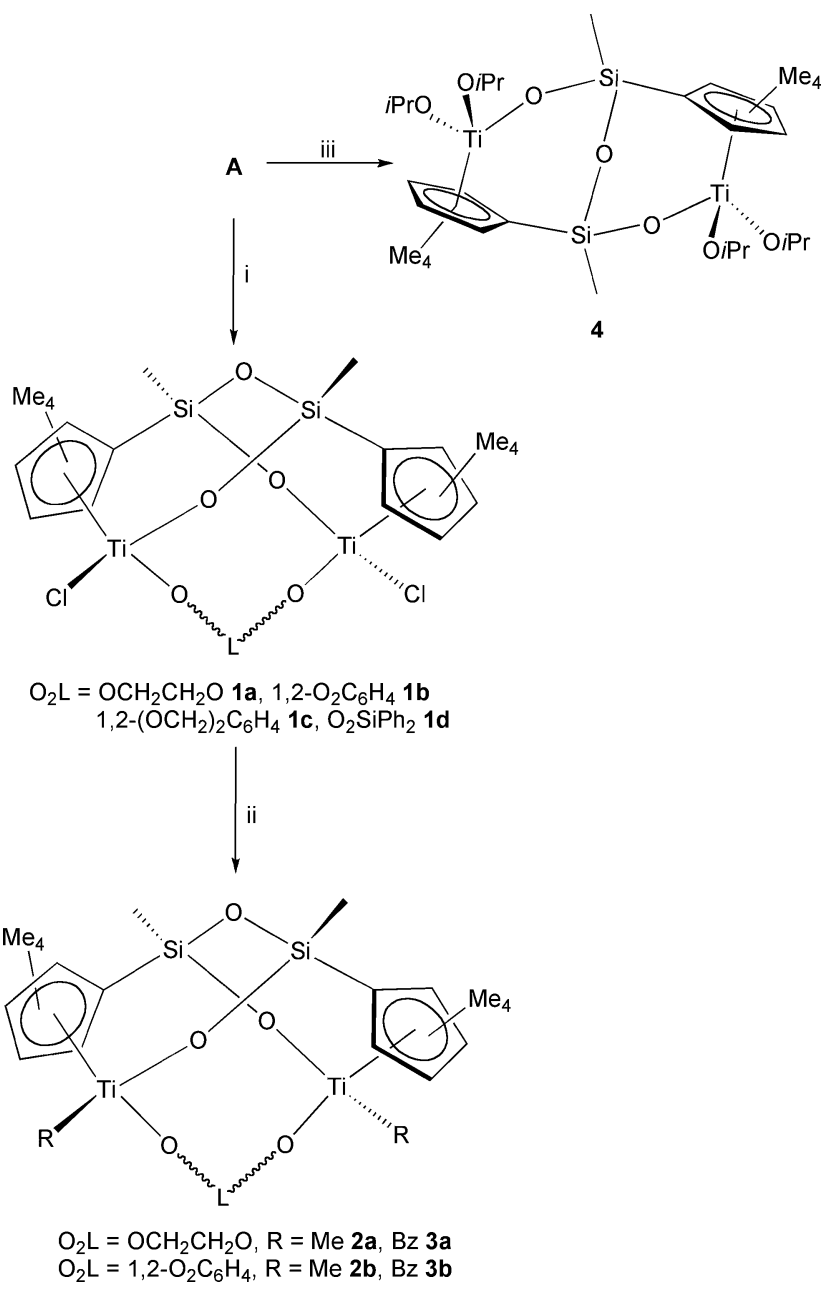

Scheme 1 (i) $\mathrm{Li}_{2}\left(\mathrm{OCH}_{2}\right)_{2}$ or $(\mathrm{HO})_{2} \mathrm{~L} / \mathrm{NEt}_{3}\left((\mathrm{HO})_{2} \mathrm{~L}=1,2-(\mathrm{HO})_{2} \mathrm{C}_{6} \mathrm{H}_{4}\right.$, 1,2-( $\left.\left(\mathrm{HOCH}_{2}\right)_{2} \mathrm{C}_{6} \mathrm{H}_{4},(\mathrm{HO})_{2} \mathrm{SiPh}_{2}\right)$, toluene; (ii) $\mathrm{ClRMg}(\mathrm{R}=\mathrm{Me}, \mathrm{Bz})$, $\mathrm{Et}_{2} \mathrm{O}$; (iii) $\mathrm{LiO} i \mathrm{Pr}$, toluene.

These new dialkoxo-bridged compounds present two new stereogenic Ti atoms in addition to the two stereogenic Si atoms. However, formation of the dialkoxo bridge, which was located opposite to the $\mathrm{Si}-\mathrm{O}-\mathrm{Si}$ bridge, was regioselective due to the presence of the disiloxane moiety; therefore signals for only one diastereoisomer were observed in the NMR spectra. Hence, the $\mathrm{C}_{2}$ symmetry complexes $\mathbf{1 a - d}$ presented an $\mathrm{ABCD}$ spin system for the equivalent $\mathrm{C}_{5} \mathrm{Me}_{4} \mathrm{Si}$ substituents, one resonance for the equivalent $\mathrm{Si}-\mathrm{Me}$ groups and the resonances corresponding for the symmetric bridge. In the particular case of the ethylene bridge of $1 \mathbf{a}$ and the methylene groups of the dialkoxo bridge of $\mathbf{1 c}$, the ${ }^{1} \mathrm{H}$ NMR spectra showed two doublets for the diastereotopic protons of both $\mathrm{CH}_{2}$ groups.

Complexes 1a and $\mathbf{1 b}$ reacted with two equiv. of $\mathrm{ClRMg}(\mathrm{R}=$ $\mathrm{Me}, \mathrm{Bz})$ to afford the alkyl derivatives $\left[(\mathrm{TiR})_{2}\left(\mu-\mathrm{O}_{2} \mathrm{~L}\right)\left(\mu-\left\{\left(\eta^{5}-\right.\right.\right.\right.$ $\left.\left.\left.\left.\mathrm{C}_{5} \mathrm{Me}_{4} \mathrm{SiMeO}\right)_{2}(\mu-\mathrm{O})\right\}\right)\right]\left(\mathrm{O}_{2} \mathrm{~L}=1,2-\mathrm{O}_{2} \mathrm{C}_{2} \mathrm{H}_{4}, \mathrm{R}=\mathrm{Me} \mathbf{2 a}, \mathrm{Bz} \mathbf{3 a}\right.$; $\mathrm{O}_{2} \mathrm{~L}=1,2-\mathrm{O}_{2} \mathrm{C}_{6} \mathrm{H}_{4}, \mathrm{R}=\mathrm{Me} 2 \mathbf{b}, \mathrm{Bz} 3 \mathbf{b}$ ) (Scheme 1). Addition of excess Grignard reagent afforded the tetraalkyl derivatives $\left[\left(\mathrm{TiR}_{2}\right)_{2}\left(\mu-\left\{\left(\eta^{5}-\mathrm{C}_{5} \mathrm{Me}_{4} \mathrm{SiMeO}\right)_{2}(\mu-\mathrm{O})\right\}\right)\right]$. The NMR spectra of complexes $\mathbf{2}$ and $\mathbf{3}$ showed similar patterns to those observed for compounds $\mathbf{1 a}$ and $\mathbf{1 b}$, with new resonances for the equivalent $\mathrm{Ti}-\mathrm{Me}$ and $\mathrm{Ti}-\mathrm{Bz}$ groups, respectively, consistent with $\mathrm{C}_{2}$-symmetric compounds. Furthermore, the ${ }^{1} \mathrm{H}$ NMR spectrum of the benzyl complexes showed two doublets for the diastereotopic $\mathrm{CH}_{2}$ protons of the benzyl ligands.

The tetraalkoxo derivative $\left[\left\{\mathrm{Ti}(\mathrm{O} i \mathrm{Pr})_{2}\right\}_{2}\left(\mu-\left\{\left(\eta^{5}-\mathrm{C}_{5} \mathrm{Me}_{4}-\right.\right.\right.\right.$ $\left.\left.\left.\mathrm{SiMeO})_{2}(\mu-\mathrm{O})\right\}\right)\right](4)$ was obtained in good yield upon addition of four equiv. of $\mathrm{LiO} i \mathrm{Pr}$ to compound $\mathrm{A}$. Compound 4 was also air sensitive but thermally stable; its ${ }^{1} \mathrm{H}$ and ${ }^{13} \mathrm{C}$ NMR spectra corresponded to a $\mathrm{C}_{2}$ symmetry complex with resonance patterns similar to those discussed for complexes 1-3. Furthermore, in the ${ }^{1} \mathrm{H}$ and ${ }^{13} \mathrm{C}$ NMR spectra two sets of resonances were observed for the two diastereotopic $\mathrm{O} i \mathrm{Pr}$ groups of each Ti atom.

\section{Reactions with the Lewis acids $E\left(C_{6} F_{5}\right)_{3}(E=B, A l)$}

Neither of the chloro derivatives $\mathbf{1 a}$ and $\mathbf{1 b}$ reacted with $\mathrm{B}\left(\mathrm{C}_{6} \mathrm{~F}_{5}\right)_{3}$. However, the ethyleneglycolate derivative 1a reacted with $\mathrm{Al}\left(\mathrm{C}_{6} \mathrm{~F}_{5}\right)_{3}$ with substitution of the dialkoxo ligand by two pentafluorophenyl groups to give $\left[\left\{\mathrm{TiCl}\left(\mathrm{C}_{6} \mathrm{~F}_{5}\right)\right\}_{2}\left(\mu-\left\{\left(\eta^{5}-\right.\right.\right.\right.$ $\left.\left.\mathrm{C}_{5} \mathrm{Me}_{4} \mathrm{SiMeO}_{2}(\mu-\mathrm{O})\right\}\right)$ ] (5) as the unique titanium product (Scheme 2). Transfer of one $\mathrm{C}_{6} \mathrm{~F}_{5}$ group from the $\mathrm{Al}$ atom to each Ti atom with exchange of the dialkoxo ligand is consistent with the higher oxophilicity of the Al atom, although we could not identify the aluminium species formed in this reaction. Compound 5 retained the $\mathrm{C}_{2}$ symmetry of the starting product $1 \mathrm{a}$, as evidenced by its NMR spectra, with the two $\mathrm{C}_{6} \mathrm{~F}_{5}$ groups located opposite to the $\mathrm{Si}-\mathrm{O}-\mathrm{Si}$ bridge, in the position previously occupied by the alkoxo bridge, consistent with the concerted mechanism of this metathesis reaction. Hence, the ${ }^{1} \mathrm{H}$ and ${ }^{13} \mathrm{C}$ NMR spectra also presented an $\mathrm{ABCD}$ spin system for the equivalent $\mathrm{C}_{5} \mathrm{Me}_{4} \mathrm{Si}$ substituents, one resonance for the equivalent $\mathrm{Si}-\mathrm{Me}$ groups, and

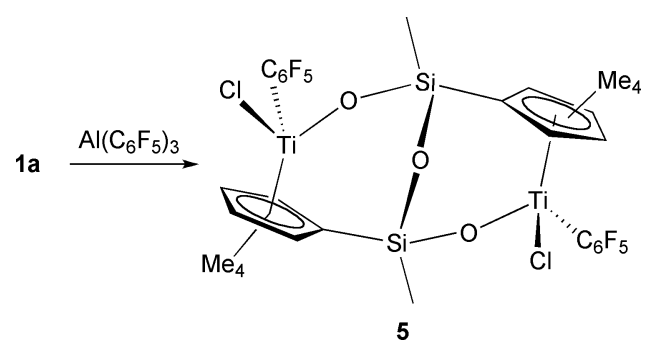

Scheme 2 
three resonances for the three types of $\mathrm{F}$ nuclei were observed in the ${ }^{19} \mathrm{~F}$ NMR spectrum for the $\mathrm{C}_{6} \mathrm{~F}_{5}$ groups.

Conversely, the reaction of $\mathrm{Al}\left(\mathrm{C}_{6} \mathrm{~F}_{5}\right)_{3}$ with the catecholatebridged complex $\mathbf{1 b}$ gave the oxo-alane adduct $\left[(\mathrm{TiCl})_{2}\left(\mu-\mathrm{O}_{2} \mathrm{~L}\right)(\mu\right.$ $\left.\left.\left\{\left(\eta^{5}-\mathrm{C}_{5} \mathrm{Me}_{4} \mathrm{SiMeO}\right)_{2}\left(\mu-\mathrm{O} \cdot \mathrm{Al}\left\{\mathrm{C}_{6} \mathrm{~F}_{5}\right\}_{3}\right)\right\}\right)\right]\left(\mathrm{O}_{2} \mathrm{~L}=1,2-\mathrm{O}_{2} \mathrm{C}_{6} \mathrm{H}_{4}\right.$ 6) (Scheme 3), which was identified by NMR spectroscopy. Formation of the oxo-alane adduct $\mathbf{6}$ at ambient temperature can be attributed to the lower accessibility of the oxygen atom in the phenylenedialkoxo-bridged complex $\mathbf{1 b}$ with respect to the ethyleneglycolate complex 1a, due to the higher steric requirement of the phenylene moiety and also to its $\pi$ acceptor capability. The ${ }^{1} \mathrm{H}$ and ${ }^{13} \mathrm{C}$ NMR spectra of $\mathbf{6}$ showed resonances very close to those of $\mathbf{1 b}$, although the most remarkable feature that confirmed the formation of an oxo-alane adduct was the ${ }^{19} \mathrm{~F}$ NMR spectrum which showed the three expected resonances characteristic of these type of complex.

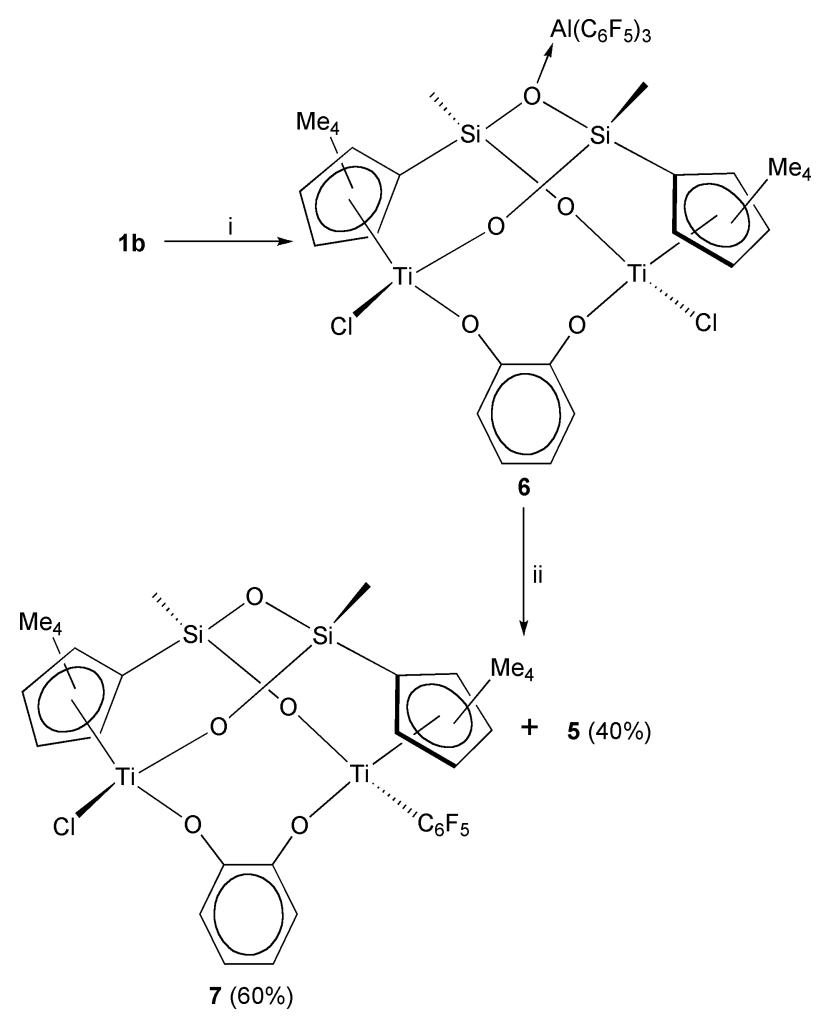

Scheme 3 (i) $\mathrm{Al}\left(\mathrm{C}_{6} \mathrm{~F}_{5}\right)_{3}, 5$ min; (ii) 3 days.

Compound 6 was unstable and further transformation occurred at ambient temperature to give a mixture of 5 and $\left[(\mathrm{TiCl})\left\{\mathrm{Ti}\left(\mathrm{C}_{6} \mathrm{~F}_{5}\right)\right\}\left(\mu-\mathrm{O}_{2} \mathrm{~L}\right)\left(\mu-\left\{\left(\eta^{5}-\mathrm{C}_{5} \mathrm{Me}_{4} \mathrm{SiMeO}\right)_{2}(\mu-\mathrm{O})\right\}\right)\right]\left(\mathrm{O}_{2} \mathrm{~L}=\right.$ 1,2- $\mathrm{O}_{2} \mathrm{C}_{6} \mathrm{H}_{4} 7$ ) in a 2:3 molar ratio after three days (Scheme 3). The resulting aluminium by-product could not be identified. This process required de-coordination of the $\mathrm{Al}\left(\mathrm{C}_{6} \mathrm{~F}_{5}\right)_{3}$ moiety from the oxygen atom in compound $\mathbf{6}$, recovering the initial reaction products as a consequence of the weak $\mathrm{O}-\mathrm{Al}$ interaction. Formation of compound $\mathbf{7}$ as the major reaction product can also be justified by the different steric and electronic characteristic of the phenylenedialkoxo bridge, with regard to the ethylenedialkoxo bridge, which would make the approach of $\mathrm{Al}\left(\mathrm{C}_{6} \mathrm{~F}_{5}\right)_{3}$ to the bridging oxygen atoms difficult, rather favouring exchange of the chloro ligand with the $\mathrm{C}_{6} \mathrm{~F}_{5}$ group. However, it is important to note that formation of 7 should be independent of the formation of adduct 6 , de-coordination of $\mathrm{Al}\left(\mathrm{C}_{6} \mathrm{~F}_{5}\right)_{3}$ from the oxygen atom of 6 is required to obtain 7 . Compound 7 is an asymmetric molecule and thus, its ${ }^{1} \mathrm{H}$ and ${ }^{13} \mathrm{C}$ NMR spectra showed resonances for two $\mathrm{C}_{5} \mathrm{Me}_{4} \mathrm{Si} \mathrm{ABCD}$ spin systems, two resonances for both SiMe groups and four multiplets for the four protons of the catecholate bridge in the ${ }^{1} \mathrm{H}$ NMR spectrum. Furthermore, three resonances for the $\mathrm{Ti}\left(\mathrm{C}_{6} \mathrm{~F}_{5}\right)$ moiety were observed in the ${ }^{19} \mathrm{~F}$ NMR spectrum.

The methyl derivatives $\mathbf{2}$, when treated with any of the Lewis acids $\mathrm{E}\left(\mathrm{C}_{6} \mathrm{~F}_{5}\right)_{3}(\mathrm{E}=\mathrm{B}, \mathrm{Al})$, decomposed even at low temperatures. In contrast, the benzyl compounds 3 reacted with one equiv. of $\mathrm{B}\left(\mathrm{C}_{6} \mathrm{~F}_{5}\right)_{3}$ to give the asymmetric monoionic complexes [Ti(TiBz)$\left.\left(\mu-\mathrm{O}_{2} \mathrm{~L}\right)\left(\mu-\left\{\left(\eta^{5}-\mathrm{C}_{5} \mathrm{Me}_{4} \mathrm{SiMeO}\right)_{2}(\mu-\mathrm{O})\right\}\right)\right]\left[\mathrm{BzB}\left(\mathrm{C}_{6} \mathrm{~F}_{5}\right)_{3}\right]\left(\mathrm{O}_{2} \mathrm{~L}=1,2-\right.$ $\mathrm{O}_{2} \mathrm{C}_{2} \mathrm{H}_{4}$ 8B, $\mathrm{O}_{2} \mathrm{~L}=1,2-\mathrm{O}_{2} \mathrm{C}_{6} \mathrm{H}_{4}$ 9B) (Scheme 4). However, 9B was unstable at ambient temperature. The same reaction employing $\mathrm{Al}\left(\mathrm{C}_{6} \mathrm{~F}_{5}\right)_{3}$ as Lewis acid afforded the analogous compound $\left[\mathrm{Ti}(\mathrm{TiBz})\left(\mu-\mathrm{O}_{2} \mathrm{~L}\right)\left(\mu-\left\{\left(\eta^{5}-\mathrm{C}_{5} \mathrm{Me}_{4} \mathrm{SiMeO}\right)_{2}(\mu-\right.\right.\right.$ $\mathrm{O})\})]\left[\mathrm{BzAl}\left(\mathrm{C}_{6} \mathrm{~F}_{5}\right)_{3}\right]\left(\mathrm{O}_{2} \mathrm{~L}=1,2-\mathrm{O}_{2} \mathrm{C}_{2} \mathrm{H}_{4} \mathbf{8 A l}\right)$ for 3a, while only decomposition was observed for the catecholate derivative $\mathbf{3 b}$. The cation of 8Al was also unstable at room temperature and was further transformed into a mixture of compounds in which the chloro-bridged compound $\left[(\mathrm{TiBz})_{2}(\mu-\mathrm{Cl})\left(\mu-\left\{\left(\eta^{5}-\right.\right.\right.\right.$ $\left.\left.\left.\left.\mathrm{C}_{5} \mathrm{Me}_{4} \mathrm{SiMeO}\right)_{2}(\mu-\mathrm{O})\right\}\right)\right]\left[\mathrm{BzAl}\left(\mathrm{C}_{6} \mathrm{~F}_{5}\right)_{3}\right]$ (10) was identified. ${ }^{36}$ The same reaction employing $\left[\mathrm{Ph}_{3} \mathrm{C}\right]\left[\mathrm{B}\left(\mathrm{C}_{6} \mathrm{~F}_{5}\right)_{4}\right]$ resulted in decomposition of the starting materials.

These $\mathrm{Ti}$ complexes are asymmetric cations presenting eight resonances for two $\mathrm{ABCD} \mathrm{C}_{5} \mathrm{Me}_{4} \mathrm{Si}$ spin systems and two resonances for both SiMe groups in their ${ }^{1} \mathrm{H}$ and ${ }^{13} \mathrm{C}$ NMR spectra. Four multiplets for the four protons of the dialkoxo bridge and two doublets for both protons of the Ti- $\mathrm{CH}_{2}$ groups were also observed in the ${ }^{1} \mathrm{H}$ NMR spectra. The ${ }^{19} \mathrm{~F}$ NMR spectra of the borate anions of derivatives $\mathbf{8 B}$ and $\mathbf{9 B}$ showed an important difference regarding the type of anion-cation interactions. ${ }^{38}$ For $\mathbf{8 B}$, with the ethylenedialkoxo bridge, the $\Delta \delta\left(\mathrm{F}_{\mathrm{p}}-\mathrm{F}_{\mathrm{m}}\right)$ of 2.8 indicated unpaired ions, whereas for $\mathbf{9 B}$, with the phenylenedialkoxo bridge, the $\Delta \delta\left(\mathrm{F}_{\mathrm{p}}-\mathrm{F}_{\mathrm{m}}\right)$ of 5.4 was indicative of an ion-pair interaction. This difference is consistent with the donor ability of each dialkoxo bridge, which is related to the $\pi$ acceptor contribution of the phenylene ring.

Addition of excess $\mathrm{E}\left(\mathrm{C}_{6} \mathrm{~F}_{5}\right)_{3}(\mathrm{E}=\mathrm{B}, \mathrm{Al})$ did not result in abstraction of the second benzyl group in these monocationic derivatives, where no reaction was observed even after heating. In addition, the abstraction did not occur in the presence of donor ligands such as THF or pyridine or by addition of one equiv. of $\left[\mathrm{Ph}_{3} \mathrm{C}\right]\left[\mathrm{B}\left(\mathrm{C}_{6} \mathrm{~F}_{5}\right)_{4}\right]$. It would seem that generation of a cationic titanium atom hinders the abstraction of the remaining benzyl ligand bounded to the other metal centre, although both titanium atoms are separated by bridges and also are bound to electronegative and $\pi$ donor oxygen atoms, which should help to stabilize the metal's electron deficiency.

\section{X-Ray diffraction studies}

The molecular structures of $\mathbf{1 a}, \mathbf{1 b}$ and $\mathbf{7}$ are illustrated in Fig. 2 and 3. Selected bond lengths and angles for these structures are listed in Table 1. The molecular structures of these three complexes consist of a dinuclear molecule formed by two Ti atoms connected by two bridging $\left[\mu-\left(\eta^{5}-C_{5} R_{4} \mathrm{SiMe}_{2} \mathrm{O}\right)\right]$ fragments, each of these $\mathrm{Ti}$ 


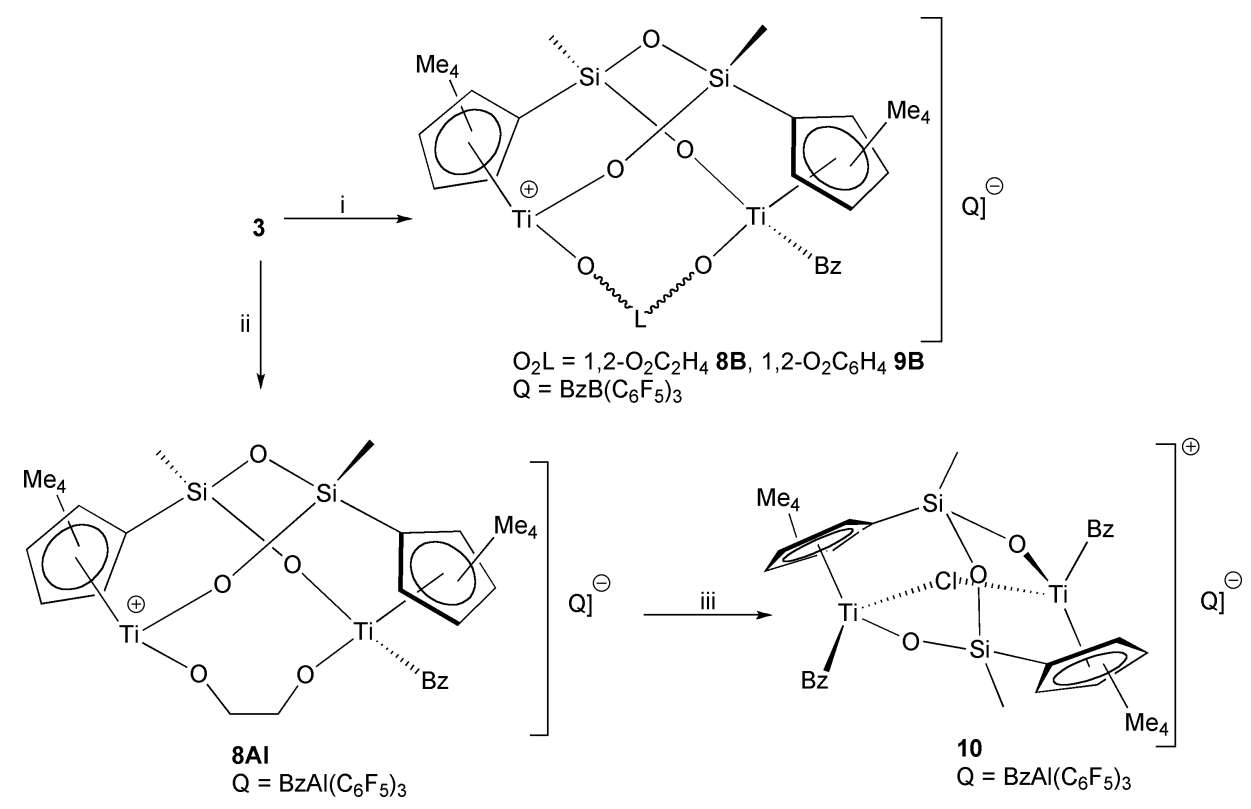

Scheme 4 (i) $\mathrm{B}\left(\mathrm{C}_{6} \mathrm{~F}_{5}\right)_{3}, \mathrm{CD}_{2} \mathrm{Cl}_{2}$; (ii) $\mathrm{Al}\left(\mathrm{C}_{6} \mathrm{~F}_{5}\right)_{3}, \mathrm{CD}_{2} \mathrm{Cl}_{2}$; (iii) $\mathrm{CD}_{2} \mathrm{Cl}_{2}$.
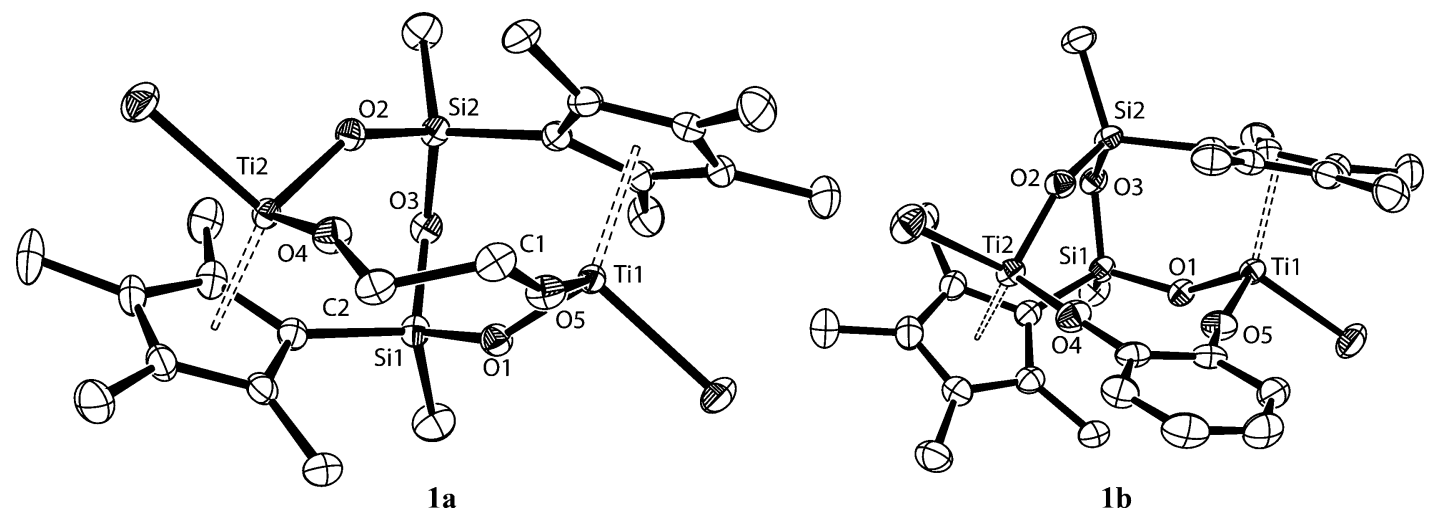

Fig. 2 ORTEP diagrams of $\left[(\mathrm{TiCl})_{2}\left(\mu-\mathrm{O}_{2} \mathrm{~L}\right)\left(\mu-\left\{\left(\eta^{5}-\mathrm{C}_{5} \mathrm{Me}_{4} \mathrm{SiMeO}\right)_{2}(\mu-\mathrm{O})\right\}\right)\right]\left(\mathrm{O}_{2} \mathrm{~L}=1,2-\mathrm{O}_{2} \mathrm{C}_{2} \mathrm{H}_{4} \mathbf{1 a}, 1,2-\mathrm{O}_{2} \mathrm{C}_{6} \mathrm{H}_{4} \mathbf{1 b}\right)$. Hydrogen atoms have been omitted and thermal ellipsoids are shown at the $30 \%$ level.

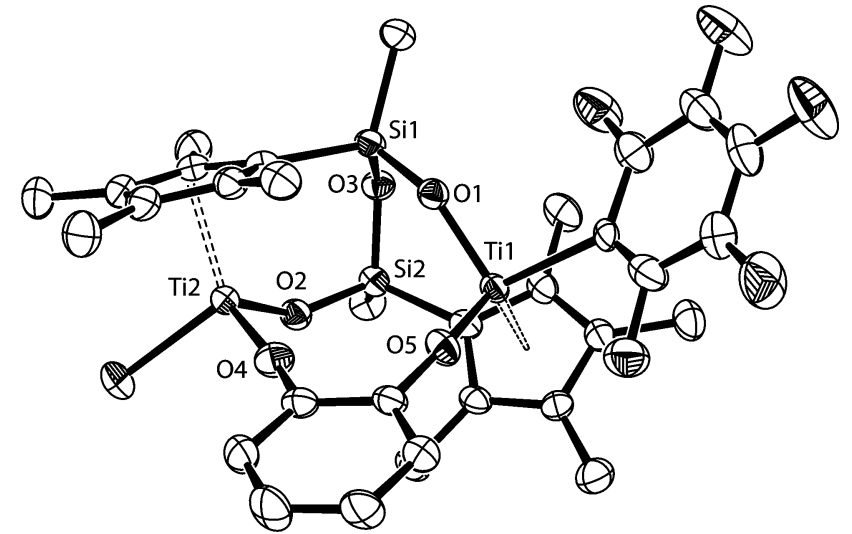

Fig. 3 ORTEP diagrams of $\left[(\mathrm{TiCl})\left\{\mathrm{Ti}\left(\mathrm{C}_{6} \mathrm{~F}_{5}\right)\right\}\left(\mu-\mathrm{O}_{2} \mathrm{~L}\right)\left(\mu-\left\{\left(\eta^{5}-\mathrm{C}_{5} \mathrm{Me}_{4^{-}}\right.\right.\right.\right.$ $\left.\left.\left.\mathrm{SiMeO})_{2}(\mu-\mathrm{O})\right\}\right)\right](7)$. Hydrogen atoms have been omitted and thermal ellipsoids are shown at the $30 \%$ level.

atoms is bound to one $\eta^{5}-\mathrm{C}_{5} \mathrm{R}_{4} \mathrm{Si}$ ring and to one oxygen atom $\kappa-O$ of the different bridges. One additional oxygen atom also links both bridges through a $\mathrm{Si}-\mathrm{O}-\mathrm{Si}$ system, retaining the initial geometry of compound A. Furthermore, both Ti atoms are also bridged by a chelating ethyleneglycolate (1a) or catecholate $(\mathbf{1 b}, \mathbf{7})$ ligands, located opposite to the $\mathrm{Si}-\mathrm{O}-\mathrm{Si}$ bridge. The environment about each Ti atom corresponds to the typical pseudo-tetrahedral geometry found in such compounds and the coordination sphere of each $\mathrm{Ti}$ atom is completed by one $\mathrm{Cl}$ ligand $(\mathbf{1 a}, \mathbf{1 b})$ or one $\mathrm{Cl}$ and one $\mathrm{C}_{6} \mathrm{~F}_{5}$ group (7).

The bond distances and angles within the $\left[\operatorname{Ti}_{2}\left(\mu-\left\{\eta^{5}-\right.\right.\right.$ $\left.\left.\mathrm{C}_{5} \mathrm{Me}_{4} \mathrm{SiMeO}_{2}\right)\right]$ moiety are very similar to $\mathbf{1 a}, \mathbf{1 b}, \mathbf{7}$ and $\mathbf{A}$ and are also close to those found for related $\mathrm{Si}-\mathrm{O}-\mathrm{Ti}$ bridged dinuclear compounds $\left[\left(\mathrm{TiCl}_{2}\right)_{2}\left(\mu-\left\{\eta^{5}-\mathrm{C}_{5} \mathrm{R}_{4} \mathrm{SiMe}_{2} \mathrm{O}\right\}_{2}\right)\right]\left(\mathrm{R}=\mathrm{H}^{32} \mathbf{B}, \mathrm{Me}^{39}\right.$ C) and $\left[\left(\mathrm{TiMe}_{2}\right)_{2}\left(\mu-\mathrm{CH}_{2}\right)\left(\mu-\left\{\eta^{5}-\mathrm{C}_{5} \mathrm{Me}_{4} \mathrm{SiMe}_{2} \mathrm{O}\right\}_{2}\right)\right]^{40}(\mathrm{D})$, with the exception of the $\mathrm{Ti}(1)-\mathrm{O}-\mathrm{Si}(1)$ angle which is clearly smaller for 1a, 1b, 7, A, due to the bridging $\mathrm{Si}-\mathrm{O}-\mathrm{Si}$ system. The tightening of this angle is also observed in the methylidene-bridged derivative D. The presence of the dialkoxo bridge in complexes $\mathbf{1 a}, \mathbf{1 b}$ and 7 causes both Ti atoms to be closer compared with $\mathbf{A}, \mathbf{B}$ and $\mathbf{C}$, although it was smaller than that observed for compound $\mathbf{D}$ with a shorter one-atom methylidene bridge.

A striking structural feature for all of these complexes is the disposition of the cyclopentadienyl rings. While for complexes 
Table 1 Selected bond distances $(\AA)$ and angles $\left(^{\circ}\right)$ of compounds $\mathbf{1 a} \cdot \mathbf{0 . 5} \mathbf{C}_{\mathbf{6}} \mathbf{H}_{\mathbf{1 4}}, \mathbf{1 b}, \mathbf{7},\left[\left(\mathrm{TiCl}_{2}\right)_{2}\left(\mu-\left\{\left(\eta^{5}-\mathrm{C}_{5} \mathrm{Me}_{4} \mathrm{SiMeO}_{2}(\mu-\mathrm{O})\right\}\right)\right](\mathbf{A}),\left[\left(\mathrm{TiCl}_{2}\right)_{2}\left(\mu-\left\{\eta^{5}-\right.\right.\right.\right.$ $\left.\left.\left.\mathrm{C}_{5} \mathrm{R}_{4} \mathrm{SiMe}_{2} \mathrm{O}\right\}_{2}\right)\right]\left(\mathrm{R}=\mathrm{H} \mathrm{B},{ }^{32} \mathrm{Me} \mathbf{C}^{39}\right)$ and $\left[\left(\mathrm{TiMe}_{2}\right)_{2}\left(\mu-\mathrm{CH}_{2}\right)\left(\mu-\left\{\eta^{5}-\mathrm{C}_{5} \mathrm{Me}_{4} \mathrm{SiMe}_{2} \mathrm{O}\right\}_{2}\right)\right]^{40}(\mathbf{D})$

\begin{tabular}{|c|c|c|c|c|c|c|c|}
\hline Complex & $1 \mathrm{a} \cdot 0.5 \mathrm{C}_{6} \mathrm{H}_{14}$ & $1 \mathrm{~b}$ & 7 & $\mathbf{A}$ & B & $\mathrm{C}$ & D \\
\hline $\mathrm{Ti}(1)-\mathrm{O}(1)$ & $1.857(3)$ & $1.837(2)$ & $1.843(3)$ & $1.803(1)$ & $1.767(2)$ & $1.771(4)$ & $1.827(1)$ \\
\hline $\mathrm{Si}(1)-\mathrm{O}(1)$ & $1.640(3)$ & $1.644(2)$ & $1.645(3)$ & $1.643(1)$ & $1.653(1)$ & $1.650(4)$ & $1.640(1)$ \\
\hline $\mathrm{Si}(1)-\mathrm{O}(3)$ & $1.655(3)$ & $1.660(2)$ & $1.658(3)$ & $1.640(1)$ & & & \\
\hline $\mathrm{Ti} \cdots \mathrm{Cp}$ & 2.061 & 2.056 & 2.049 & 2.038 & 2.026 & 2.031 & 2.058 \\
\hline $\mathrm{Ti} \cdots \mathrm{Ti}$ & 4.467 & 4.479 & 4.434 & 5.193 & 5.255 & 5.099 & 3.371 \\
\hline $\mathrm{Si} \cdots \mathrm{Si}$ & 2.864 & 2.891 & 2.889 & 2.845 & 4.700 & 4.829 & 4.535 \\
\hline $\mathrm{Ti}(1)-\mathrm{O}(1)-\mathrm{Si}(1)$ & $148.98(18)$ & $149.03(12)$ & $147.47(17)$ & $147.96(9)$ & $160.2(1)$ & $159.8(2)$ & $150.09(7)$ \\
\hline $\mathrm{Ti}(2)-\mathrm{O}(2)-\mathrm{Si}(2)$ & $146.65(17)$ & $143.59(12)$ & $147.56(16)$ & & & & \\
\hline $\mathrm{PCp} \cdots \mathrm{O}^{a}$ & 1.005 & 0.828 & 0.931 & 0.463 & 0.631 & 1.047 & 1.625 \\
\hline $\mathrm{Si}(1)-\mathrm{O}(3)-\mathrm{Si}(2)$ & $119.06(16)$ & $121.12(11)$ & $120.83(16)$ & $120.2(1)$ & & & \\
\hline $\mathrm{C}-\mathrm{Si}(1)-\mathrm{O}(1)$ & $109.02(16)$ & $108.04(11)$ & $100.96(19)$ & 108.63 & 106.40 & 108.29 & 107.21 \\
\hline $\mathrm{Ti}(2)-\mathrm{O}(4)$ & $1.778(3)$ & $1.810(2)$ & $1.813(3)$ & & & & \\
\hline $\mathrm{Ti}(1)-\mathrm{O}(5)$ & 1.794(3) & $1.818(2)$ & $1.815(3)$ & & & & \\
\hline $\mathrm{Ti}(1)-\mathrm{O}(5)-\mathrm{C}$ & $158.0(3)$ & 166.61(19) & $169.6(3)$ & & & & \\
\hline Ti(2)-O(4)-C & 162.1(3) & $163.73(19)$ & $165.8(3)$ & & & & \\
\hline $\mathrm{O}(5)-\mathrm{C}(1)-\mathrm{C}(2)$ & $110.5(3)$ & $119.8(12)$ & 119.7(3) & & & & \\
\hline $\mathrm{PCp}-\mathrm{PCp}^{a}$ & 50.60 & 43.11 & 44.70 & 29.06 & 0.000 & 0.000 & 28.78 \\
\hline
\end{tabular}

${ }^{a}$ PCp stands for the plane containing the cyclopentadienyl ring and PCp-PCp corresponds to the angle formed by planes containing both cyclopentadienyl ligands.

$\mathbf{B}$ and $\mathbf{C}$ the planes containing the cyclopentadienyl ligands are parallel, for $\mathbf{A}$ and $\mathbf{D}$, with one additional bridge between the $\mathrm{Si}$ and $\mathrm{Ti}$ atoms respectively, they form an angle of about $30^{\circ}$. Furthermore, the presence of the dialkoxo bridge between the $\mathrm{Ti}$ atoms in complexes $\mathbf{1 a}, \mathbf{1 b}$ and $\mathbf{7}$ forces this angle to open, also noting an increasing value from $\mathbf{1 b}$ and $\mathbf{7}$, with the planar phenylenedialkoxo bridge, with respect to the ethylenedialkoxobridged compound 1a.

The molecular structures of all of these complexes $(\mathbf{1 a}, \mathbf{1 b}, \mathbf{7}$, A-D) resembles that of the dinuclear derivative $\left[\left(\mathrm{TiCl}_{2}\right)_{2}\left(\mu-\left\{\left(\eta^{5}-\right.\right.\right.\right.$ $\left.\left.\left.\left.\mathrm{C}_{5} \mathrm{H}_{4} \mathrm{~B}\left\{\mathrm{NHMe}_{2}\right\} \mathrm{O}\right)_{2}(\mu-\mathrm{O})\right\}\right)\right]{ }^{41}$ In this last case, the smaller size of the boron atom favours the approximation of both Ti atoms to a value (4.647 $\AA$ ) similar to those observed in the alkoxobridged compounds 1a, 1b and 7, although the angle between the cyclopentadienyl rings of $27.60^{\circ}$ is comparable with that of $\mathbf{A}$, without dialkoxo bridges.

\section{Polymerization of $\varepsilon$-caprolactone ( $\varepsilon-\mathrm{CL})$}

The dinuclear dialkoxo-bridged $\mathbf{1 a}$ and $\mathbf{1 b}$ and tetraalkoxo $\mathbf{4}$ and the mononuclear trialkoxo $\left[\mathrm{TiCp} *(\mathrm{O} i \mathrm{Pr})_{3}\right](\mathbf{E})$ complexes were tested as catalysts for the polymerization of $\varepsilon$-CL (Table 2). Whereas no activity was observed for the chloro derivatives $\mathbf{1 a}$ and $\mathbf{1 b}$, the alkoxo complexes $\mathbf{4}$ and $\mathbf{E}$ displayed parallel behaviour in the polymerization conditions, the yield obtained at $100{ }^{\circ} \mathrm{C}$ was lower $(\mathrm{ca} .13 \%)$ than that at $140^{\circ} \mathrm{C}(\mathrm{ca} .75 \%)$. The results observed with compound $\mathbf{E}$ were also are very similar to those reported for $\left[\mathrm{TiCp}(\mathrm{O} i \mathrm{Pr})_{3}\right] .^{42}$

These polymers showed a striking difference among themselves with respect to their molecular weight, which for the dinuclear compound 4 was close to twice the molecular weight of PCL obtained with the mononuclear derivative E. Probably, in the dinuclear compound $\mathbf{4}$ the proximity of both titanium atoms allows polymerization at only one of them, with the other titanium atom blocked by the growing chain. Similar behaviour was described for a titanium-aluminium dinuclear compound. ${ }^{43}$

Activation of $\varepsilon-\mathrm{CL}$ with complexes $\mathbf{4}$ and $\mathbf{E}$ proceeded in both cases by cleavage of the acyl-oxygen bond, confirmed by ${ }^{1} \mathrm{H}$ NMR spectroscopy with the resonances at about $\delta 5.0$ and $\delta 1.3$ ascribed to an ester isopropoxy group. ${ }^{16-23}$

\section{Conclusions}

The dinuclear compound with $\mathrm{Ti}-\mathrm{O}-\mathrm{Si}$ and $\mathrm{Si}-\mathrm{O}-\mathrm{Si}$ bridges $\left[\left(\mathrm{TiCl}_{2}\right)_{2}\left(\mu-\left\{\left(\eta^{5}-\mathrm{C}_{5} \mathrm{Me}_{4} \mathrm{SiMeO}\right)_{2}(\mu-\mathrm{O})\right\}\right)\right]$ reacts with dilithium salts or diols to give the new dinuclear complexes with bridging dialkoxo ligands $\left[(\mathrm{TiCl})_{2}\left(\mu-\mathrm{O}_{2} \mathrm{~L}\right)\left(\mu-\left\{\left(\eta^{5}-\mathrm{C}_{5} \mathrm{Me}_{4} \mathrm{SiMeO}\right)_{2}(\mu-\mathrm{O})\right\}\right)\right]$ $\left(\mathrm{O}_{2} \mathrm{~L}=\mathrm{OCH}_{2} \mathrm{CH}_{2} \mathrm{O}\right.$ 1a, 1,2- $\mathrm{O}_{2} \mathrm{C}_{6} \mathrm{H}_{4} \mathbf{1 b}, 1,2-\left(\mathrm{OCH}_{2}\right)_{2} \mathrm{C}_{6} \mathrm{H}_{4}$ 1c, $\mathrm{O}_{2} \mathrm{SiPh}_{2}$ 1d). These complexes are stable and are also obtained in good yield for the four-membered bridged derivatives 1a and 1 b.

Table 2 E-CL polymerization with complexes $\left[\left\{\mathrm{Ti}(\mathrm{O} i \mathrm{Pr})_{2}\right\}_{2}\left(\mu-\left\{\left(\eta^{5}-\mathrm{C}_{5} \mathrm{Me}_{4} \mathrm{SiMeO}\right)_{2}(\mu-\mathrm{O})\right\}\right)\right](4)$ and $\left[\mathrm{TiCp} *(\mathrm{O} i \mathrm{Pr})_{3}\right](\mathbf{E})^{a}$

\begin{tabular}{llllll}
\hline Run & Complex & $T /{ }^{\circ} \mathrm{C}$ & PCL/g & Yield (\%) & $\mathrm{Mw}^{b} / 10^{4}$ \\
\hline 1 & $\mathbf{E}$ & 100 & 0.14 & 14 & - \\
2 & $\mathbf{4}$ & 100 & 0.12 & 12 & - \\
3 & $\mathbf{E}$ & 140 & 0.76 & 76 & -1.63 \\
4 & $\mathbf{4}$ & 140 & 0.75 & 75 & 2.95
\end{tabular}

${ }^{a}$ Polymerization conditions: dinuclear complexes $[4]=0.04 \mathrm{mmol}$ and mononuclear complex $[\mathrm{E}]=0.08 \mathrm{mmol}$, toluene $(5 \mathrm{~mL}), 1 \mathrm{~g} \varepsilon$-caprolactone, [ $\varepsilon$-caprolactone $] /[n \mathrm{Ti}]=110(n=$ number of titanium atoms per molecule $) .{ }^{b}$ Determined by GPC in THF $v s$. polystyrene standard. 
The reactivity of the chloro derivatives $\mathbf{1 a}$ and $\mathbf{1 b}$ toward $\mathrm{Al}\left(\mathrm{C}_{6} \mathrm{~F}_{5}\right)_{3}$ depends on the type of bridging dialkoxo ligand, the ethyleneglycolate bridge is totally transferred to aluminium whereas substitution of one chloro ligand is preferred for the catecholate-bridged compound 1b. This difference is attributed to the lesser accessibility of the $\pi$ electrons of the oxygen atoms in this last type of bridging group, due to higher arene ring acidity, which should hinder the interaction with the Lewis acid.

Reactions of the corresponding benzyl derivatives $\left[(\mathrm{TiBz})_{2}(\mu-\right.$ $\left.\left.\mathrm{O}_{2} \mathrm{~L}\right)\left(\mu-\left\{\left(\eta^{5}-\mathrm{C}_{5} \mathrm{Me}_{4} \mathrm{SiMeO}\right)_{2}(\mu-\mathrm{O})\right\}\right)\right]\left(\mathrm{O}_{2} \mathrm{~L}=\mathrm{OCH}_{2} \mathrm{CH}_{2} \mathrm{O}\right.$ 3a, 1, 2$\left.\mathrm{O}_{2} \mathrm{C}_{6} \mathrm{H}_{4} 3 \mathrm{~b}\right)$ with the Lewis acids $\mathrm{E}\left(\mathrm{C}_{6} \mathrm{~F}_{5}\right)_{3}(\mathrm{E}=\mathrm{B}, \mathrm{Al})$ showed behaviour that was also dependent on the dialkoxo bridge. In both cases, abstraction of one benzyl group occurred, although ${ }^{19} \mathrm{~F}$ NMR spectroscopic measurements indicated the absence of ion-pairing for the ethyleneglycolate derivative whereas an ionpairing interaction was observed for the catecholate compound. Again, this difference is attributed to the diverse donor ability of the bridging dialkoxo ligands.

Polymerization of $\varepsilon$-CL with the tetraalkoxo dinuclear compound $\left[\left\{\mathrm{Ti}(\mathrm{O} i \mathrm{Pr})_{2}\right\}_{2}\left(\mu-\left\{\left(\eta^{5}-\mathrm{C}_{5} \mathrm{Me}_{4} \mathrm{SiMeO}\right)_{2}(\mu-\mathrm{O})\right\}\right)\right](4)$ and with the mononuclear derivative $\left[\mathrm{TiCp} *(\mathrm{O} i \mathrm{Pr})_{3}\right](\mathbf{E})$ gave polycaprolactone in good yield at high temperature, while the chloro derivatives were inactive. The $\varepsilon$-CL was activated by the nucleophilic attack of an isopropoxo ligand on the acyl carbon atom, as was shown by ${ }^{1} \mathrm{H}$ NMR of the PCL.

\section{Experimental section}

\section{General considerations}

All manipulations were carried out under an argon atmosphere and solvents were purified from appropriate drying agents. NMR spectra were recorded at $400.13\left({ }^{1} \mathrm{H}\right), 376.70\left({ }^{19} \mathrm{~F}\right)$ and $100.60\left({ }^{13} \mathrm{C}\right) \mathrm{MHz}$ on a Bruker AV400. Chemical shifts $(\delta)$ are given in ppm. ${ }^{1} \mathrm{H}$ and ${ }^{13} \mathrm{C}$ resonances were measured relative to solvent peaks considering TMS $=0 \mathrm{ppm}$, meanwhile ${ }^{19} \mathrm{~F}$ resonance were measured relative to external $\mathrm{CFCl}_{3}$. Assignment of resonances was made from HMQC and HMBC NMR experiments. Elemental analyses were performed on a Perkin-Elmer 240C. $(\mathrm{HO})_{2} \mathrm{~L}\left((\mathrm{HO})_{2} \mathrm{~L}=\mathrm{HOCH}_{2} \mathrm{CH}_{2} \mathrm{OH}\right.$, 1,2$\left.(\mathrm{HO})_{2} \mathrm{C}_{6} \mathrm{H}_{4}, 1,2-\left(\mathrm{HOCH}_{2}\right)_{2} \mathrm{C}_{6} \mathrm{H}_{4},(\mathrm{HO})_{2} \mathrm{SiPh}_{2}\right)$ and $\mathrm{LiO} i \mathrm{Pr}$ were purchased from Aldrich, degassed and stored under argon with molecular sieves $\left(\mathrm{HOCH}_{2} \mathrm{CH}_{2} \mathrm{OH}\right)$ or sublimed $\left((\mathrm{HO})_{2} \mathrm{~L}=1,2\right.$ (HO) $\left.)_{2} \mathrm{C}_{6} \mathrm{H}_{4}, 1,2-\left(\mathrm{HOCH}_{2}\right)_{2} \mathrm{C}_{6} \mathrm{H}_{4},(\mathrm{HO})_{2} \mathrm{SiPh}_{2}\right) . \mathrm{Li}_{2}\left(\mathrm{OCH}_{2}\right)_{2}$ was prepared by addition of 2 equiv. of $\mathrm{LiBu}$ to $\mathrm{HOCH}_{2} \mathrm{CH}_{2} \mathrm{OH}$ in hexane. Compounds $\left[\left(\mathrm{TiCl}_{2}\right)_{2}\left(\mu-\left\{\left(\eta^{5}-\mathrm{C}_{5} \mathrm{Me}_{4} \mathrm{SiMeO}\right)_{2}(\mu-\mathrm{O})\right\}\right)\right],{ }^{36}$ $\mathrm{B}\left(\mathrm{C}_{6} \mathrm{~F}_{5}\right)_{3}{ }^{44}$ 0.5(toluene) $\mathrm{Al}\left(\mathrm{C}_{6} \mathrm{~F}_{5}\right)_{3}{ }^{45}$ and $\left[\mathrm{Ph}_{3} \mathrm{C}\right]\left[\mathrm{B}\left(\mathrm{C}_{6} \mathrm{~F}_{5}\right)_{4}\right]^{46}$ were prepared by literature methods and $\left[\mathrm{TiCp} *(\mathrm{O} i \mathrm{Pr})_{3}\right]^{47}$ was prepared from $\left[\mathrm{TiCp} * \mathrm{Cl}_{3}\right]^{48}$ and $\mathrm{Li}(\mathrm{O} i \mathrm{Pr})$ in toluene.

$\left[(\mathrm{TiCl})_{2}\left(\boldsymbol{\mu}-1,2-\mathrm{O}_{2} \mathrm{C}_{2} \mathrm{H}_{4}\right)\left(\boldsymbol{\mu}-\left\{\left(\eta^{5}-\mathrm{C}_{5} \mathrm{Me}_{4} \mathrm{SiMeO}\right)_{2}(\boldsymbol{\mu}-\mathrm{O})\right\}\right)\right] \quad$ (1a). A suspension of $\left[\left(\mathrm{TiCl}_{2}\right)_{2}\left(\mu-\left\{\left(\eta^{5}-\mathrm{C}_{5} \mathrm{Me}_{4} \mathrm{SiMeO}\right)_{2}(\mu-\mathrm{O})\right\}\right)\right](0.60 \mathrm{~g}$, $0.98 \mathrm{mmol})$ and $\mathrm{Li}_{2}\left(\mathrm{OCH}_{2}\right)_{2}(0.11 \mathrm{~g}, 1.47 \mathrm{mmol})$ was stirred in toluene $(30 \mathrm{~mL})$ for $5 \mathrm{~h}$ at ambient temperature. Afterwards, hexane $(10 \mathrm{~mL})$ was added and the solution was filtered. The yellow residue was extracted again into a mixture of solvents toluene-hexane $(20 \mathrm{~mL} / 10 \mathrm{~mL})$. The volatiles were removed under vacuum, leaving a yellow solid $(0.35 \mathrm{~g}, 60 \%)$. Data for 1a: ${ }^{1} \mathrm{H}-\mathrm{NMR}\left(\mathrm{C}_{6} \mathrm{D}_{6}\right): 0.39$ (s, $\left.6 \mathrm{H}, \mathrm{SiMe}\right), 1.72$ (s, $\left.6 \mathrm{H}, \mathrm{C}_{5} M e_{4}\right), 2.17$ (s, $\left.6 \mathrm{H}, \mathrm{C}_{5} M e_{4}\right), 2.25\left(\mathrm{~s}, 6 \mathrm{H}, \mathrm{C}_{5} M e_{4}\right), 2.30\left(\mathrm{~s}, 6 \mathrm{H}, \mathrm{C}_{5} M e_{4}\right), 3.54$ $\left(\mathrm{dd}, 2 \mathrm{H},{ }^{2} \mathrm{~J}=8 \mathrm{~Hz},{ }^{3} \mathrm{~J}=2 \mathrm{~Hz}, \mathrm{O}_{2} \mathrm{C}_{2} H_{4}\right), 4.63\left(\mathrm{dd}, 2 \mathrm{H},{ }^{2} \mathrm{~J}=8 \mathrm{~Hz}\right.$, $\left.{ }^{3} \mathrm{~J}=2 \mathrm{~Hz}, \mathrm{O}_{2} \mathrm{C}_{2} H_{4}\right) ;{ }^{13} \mathrm{C}-\mathrm{NMR}\left(\mathrm{C}_{6} \mathrm{D}_{6}\right):-0.6(\mathrm{Si} M e), 10.7,13.4$, 14.0 and $14.1\left(\mathrm{C}_{5} M e_{4}\right), 75.8\left(\mathrm{O}_{2} \mathrm{C}_{2} \mathrm{H}_{4}\right), 122.3,129.3,134.2,134.9$ and $136.3\left(C_{5} \mathrm{Me}_{4}\right)$. Anal. Calcd for $\mathrm{C}_{22} \mathrm{H}_{34} \mathrm{O}_{5} \mathrm{Si}_{2} \mathrm{Ti}_{2} \mathrm{Cl}_{2}$ (600.57): C, 43.94; H, 5.66\%. Found: C, 44.75; H, 5.36\%.

$\left[(\mathrm{TiCl})_{2}\left(\boldsymbol{\mu}-1,2-\mathrm{O}_{2} \mathrm{C}_{6} \mathrm{H}_{4}\right)\left(\boldsymbol{\mu}-\left\{\left(\eta^{5}-\mathrm{C}_{5} \mathrm{Me}_{4} \mathrm{SiMeO}\right)_{2}(\boldsymbol{\mu}-\mathrm{O})\right\}\right)\right] \quad$ (1b). A solution of $\left[\left(\mathrm{TiCl}_{2}\right)_{2}\left(\mu-\left\{\left(\eta^{5}-\mathrm{C}_{5} \mathrm{Me}_{4} \mathrm{SiMeO}\right)_{2}(\mu-\mathrm{O})\right\}\right)\right](1.00 \mathrm{~g}$, $1.63 \mathrm{mmol})$ in toluene $(50 \mathrm{~mL})$ was treated with two equivalents of $\mathrm{NEt}_{3}(0.33 \mathrm{~g}, 3.26 \mathrm{mmol})$ and one equivalent of catechol $\left(1,2-(\mathrm{OH})_{2} \mathrm{C}_{6} \mathrm{H}_{4}, 0.18 \mathrm{~g}, 1.63 \mathrm{mmol}\right)$. The mixture was stirred overnight at ambient temperature. Hexane $(30 \mathrm{~mL})$ was then added and the solution was filtered. The red residue was extracted again into a mixture of solvents toluene-hexane (30 $\mathrm{mL} / 20 \mathrm{~mL}$ ). The volatiles were pumped off yielding $\mathbf{1 b}$ as a red solid $(0.90 \mathrm{~g}, 85 \%)$. Data for $1 \mathrm{~b}:{ }^{1} \mathrm{H}-\mathrm{NMR}\left(\mathrm{C}_{6} \mathrm{D}_{6}\right): 0.35$ (s, 6 $\mathrm{H}, \mathrm{Si} M e), 1.72\left(\mathrm{~s}, 6 \mathrm{H}, \mathrm{C}_{5} M e_{4}\right), 2.01\left(\mathrm{~s}, 6 \mathrm{H}, \mathrm{C}_{5} M e_{4}\right), 2.20$ (s, 6 $\left.\mathrm{H}, \mathrm{C}_{5} M e_{4}\right), 2.25\left(\mathrm{~s}, 6 \mathrm{H}, \mathrm{C}_{5} M e_{4}\right), 6.67\left(\mathrm{~m}, 2 \mathrm{H}, \mathrm{O}_{2} \mathrm{C}_{6} H_{4}\right), 6.93$ $\left(\mathrm{m}, 2 \mathrm{H}, \mathrm{O}_{2} \mathrm{C}_{6} H_{4}\right) ;{ }^{13} \mathrm{C}-\mathrm{NMR}\left(\mathrm{C}_{6} \mathrm{D}_{6}\right):-0.8(\mathrm{SiMe}), 11.0,12.9$, 13.4 and $14.2\left(\mathrm{C}_{5} M e_{4}\right), 120.2,122.9$ and $155.6(\mathrm{Ci})\left(\mathrm{O}_{2} \mathrm{C}_{6} \mathrm{H}_{4}\right)$, 123.4, 132.4, 134.5, 136.7 and $138.5\left(C_{5} \mathrm{Me}_{4}\right)$. Anal. Calcd for $\mathrm{C}_{26} \mathrm{H}_{34} \mathrm{O}_{5} \mathrm{Si}_{2} \mathrm{Ti}_{2} \mathrm{Cl}_{2}$ (648.62): C, 48.10; H, 5.24\%. Found: C, 49.06; $\mathrm{H}, 5.28 \%$.

I(TiCl $\left.)_{2}\left\{\boldsymbol{\mu}-1,2-\left(\mathrm{OCH}_{2}\right)_{2} \mathrm{C}_{6} \mathrm{H}_{4}\right\}\left(\boldsymbol{\mu}-\left\{\left(\boldsymbol{\eta}^{5}-\mathrm{C}_{5} \mathrm{Me}_{4} \mathrm{SiMeO}\right)_{2}(\boldsymbol{\mu}-\mathrm{O})\right\}\right)\right]$ (1c). A solution of $\left[\left(\mathrm{TiCl}_{2}\right)_{2}\left(\mu-\left\{\left(\eta^{5}-\mathrm{C}_{5} \mathrm{Me}_{4} \mathrm{SiMeO}\right)_{2}(\mu-\mathrm{O})\right\}\right)\right]$ $(0.70 \mathrm{~g}, 1.14 \mathrm{mmol})$ in toluene $(50 \mathrm{~mL})$ was treated with two equivalents of $\mathrm{NEt}_{3}(0.23 \mathrm{~g}, 2.28 \mathrm{mmol})$ and one equivalent of 1,2-benzenedimethanol $(0.15 \mathrm{~g}, 1.14 \mathrm{mmol})$. The mixture was stirred overnight at ambient temperature. Hexane $(30 \mathrm{~mL})$ was added and the solution was filtered. The yellow residue was extracted again into a mixture of solvents toluene-hexane $(30 \mathrm{~mL} /$ $20 \mathrm{~mL}$ ). The volatiles were pumped off yielding a yellow solid $(0.20 \mathrm{~g})$. The isolated solid consisted mainly of $\mathbf{1 c}$, but it contained some irremovable decomposition products, which prevented us from obtaining a correct elemental analysis, though satisfactory spectroscopy data were obtained. Data for 1c: ${ }^{1} \mathrm{H}-\mathrm{NMR}\left(\mathrm{CDCl}_{3}\right)$ : 0.33 (s, $6 \mathrm{H}, \mathrm{Si} M e$ ), 1.96 (s, $6 \mathrm{H}, \mathrm{C}_{5} M e_{4}$ ), 2.06 (s, $6 \mathrm{H}, \mathrm{C}_{5} M e_{4}$ ), $2.22\left(\mathrm{~s}, 6 \mathrm{H}, \mathrm{C}_{5} M e_{4}\right), 2.26\left(\mathrm{~s}, 6 \mathrm{H}, \mathrm{C}_{5} M e_{4}\right), 5.50\left(\mathrm{~d}, 2 \mathrm{H},{ }^{2} \mathrm{~J}=\right.$ $\left.12 \mathrm{~Hz},\left(\mathrm{OCH}_{2}\right)_{2} \mathrm{C}_{6} \mathrm{H}_{4}\right), 5.33\left(\mathrm{~d}, 2 \mathrm{H},{ }^{2} \mathrm{~J}=12 \mathrm{~Hz},\left(\mathrm{OCH}_{2}\right)_{2} \mathrm{C}_{6} \mathrm{H}_{4}\right)$, 7.32 (bs, $\left.4 \mathrm{H},\left(\mathrm{OCH}_{2}\right)_{2} \mathrm{C}_{6} H_{4}\right) ;{ }^{13} \mathrm{C}-\mathrm{NMR}\left(\mathrm{CDCl}_{3}\right):-1.0(\mathrm{SiMe})$, 11.2, 13.3, 13.7 and $13.9\left(\mathrm{C}_{5} \mathrm{Me}_{4}\right), 64.2\left(\left(\mathrm{OCH}_{2}\right)_{2} \mathrm{C}_{6} \mathrm{H}_{4}\right), 123.4$, 132.4, 134.5 and $136.1\left(C_{5} \mathrm{Me}_{4}\right), 129.0,131.3$ and $139.3\left(C_{i}\right)$ $\left(\left(\mathrm{OCH}_{2}\right)_{2} \mathrm{C}_{6} \mathrm{H}_{4}\right)$.

$\left[(\mathrm{TiCl})_{2}\left(\boldsymbol{\mu}-\mathrm{O}_{2} \mathrm{SiPh}_{2}\right)\left(\boldsymbol{\mu}-\left\{\left(\eta^{5}-\mathrm{C}_{5} \mathrm{Me}_{4} \mathrm{SiMeO}\right)_{2}(\mu-\mathrm{O})\right\}\right)\right] \quad$ (1d). A solution of $\left[\left(\mathrm{TiCl}_{2}\right)_{2}\left(\mu-\left\{\left(\eta^{5}-\mathrm{C}_{5} \mathrm{Me}_{4} \mathrm{SiMeO}\right)_{2}(\mu-\mathrm{O})\right\}\right)\right] \quad(0.20 \mathrm{~g}$, $0.32 \mathrm{mmol})$ in dichloromethane $(20 \mathrm{~mL})$ was treated with two equivalents of $\mathrm{NEt}_{3}(0.06 \mathrm{~g}, 0.64 \mathrm{mmol})$ and one equivalent of $(\mathrm{HO})_{2} \mathrm{SiPh}_{2}(0.08 \mathrm{~g}, 0.32 \mathrm{mmol})$. The mixture was stirred for three days at ambient temperature. The volatiles were then pumped off and the remaining solid was extracted into a mixture of solvents toluene-hexane $(20 \mathrm{~mL} / 10 \mathrm{~mL})$. The volatiles were pumped off yielding a yellow solid $(0.10 \mathrm{~g})$. The isolated solid consisted mainly of 1d, but it contained some irremovable decomposition products, which prevent us from obtaining correct elemental analysis, though satisfactory spectroscopy data were obtained. Data for 1d: ${ }^{1} \mathrm{H}-\mathrm{NMR}\left(\mathrm{CDCl}_{3}\right): 0.43(\mathrm{~s}, 6 \mathrm{H}, \mathrm{Si} M e), 1.81(\mathrm{~s}, 6 \mathrm{H}$, $\left.\mathrm{C}_{5} M e_{4}\right), 1.95\left(\mathrm{~s}, 6 \mathrm{H}, \mathrm{C}_{5} M e_{4}\right), 2.32\left(\mathrm{~s}, 6 \mathrm{H}, \mathrm{C}_{5} M e_{4}\right), 2.36(\mathrm{~s}, 6 \mathrm{H}$, 
$\left.\mathrm{C}_{5} \mathrm{Me}_{4}\right), 7.30\left(\mathrm{~m}, 6 \mathrm{H}, \mathrm{C}_{6} H_{5}\right), 7.63\left(\mathrm{~m}, 4 \mathrm{H}, \mathrm{C}_{6} H_{5}\right) ;{ }^{13} \mathrm{C}-\mathrm{NMR}$ $\left(\mathrm{CDCl}_{3}\right)$ : -0.8 (SiMe), 11.4, 13.3, 14.3 and $15.7\left(\mathrm{C}_{5} \mathrm{Me}_{4}\right), 122.2$, 135.2, 137.1, 138.3 and $138.6\left(C_{5} \mathrm{Me}_{4}\right), 127.7,129.84,134.3$ and $133.1\left(C_{i}\right)\left(C_{6} \mathrm{H}_{5}\right)$.

[(TiMe $\left.)_{2}\left(\mu-1,2-\mathrm{O}_{2} \mathrm{C}_{2} \mathrm{H}_{4}\right)\left(\mu-\left\{\left(\eta^{5}-\mathrm{C}_{5} \mathrm{Me}_{4} \mathrm{SiMeO}\right)_{2}(\mu-\mathrm{O})\right\}\right)\right] \quad$ (2a). A solution of $1 \mathrm{a}(0.56 \mathrm{~g}, 0.93 \mathrm{mmol})$ in diethyl ether $(40 \mathrm{~mL})$ at $-78{ }^{\circ} \mathrm{C}$ was treated with two equivalents of a solution of LiMe $(1,5 \mathrm{M}, 1.24 \mathrm{~mL}, 1.86 \mathrm{mmol})$. The reaction mixture was warmed to room temperature and stirred overnight. $10 \mathrm{~mL}$ of hexane was then added and the solution was filtered. The yellow residue was extracted again into a mixture of solvents diethyl ether-hexane $(20 \mathrm{~mL} / 10 \mathrm{~mL})$. The volatiles were pumped off to give a mixture of compounds $\mathbf{2 a}$ and [(TiMe $\left.)_{2}\left(\mu-\left\{\left(\eta^{5}-\mathrm{C}_{5} \mathrm{Me}_{4} \mathrm{SiMeO}\right)_{2}(\mu-\mathrm{O})\right\}\right)\right]$ $(0.36 \mathrm{~g})$ in 3: 1 molar ratio. Data for $2 \mathrm{a}:{ }^{1} \mathrm{H}-\mathrm{NMR}\left(\mathrm{C}_{6} \mathrm{D}_{6}\right): 0.45(\mathrm{~s}$, $6 \mathrm{H}, \mathrm{Si} M e$ ), 0.82 (s, $6 \mathrm{H}, M e-\mathrm{Ti}), 1.67$ (s, $\left.6 \mathrm{H}, \mathrm{C}_{5} M e_{4}\right), 1.98$ (s, 6 $\left.\mathrm{H}, \mathrm{C}_{5} M e_{4}\right), 2.20\left(\mathrm{~s}, 6 \mathrm{H}, \mathrm{C}_{5} M e_{4}\right), 2.47\left(\mathrm{~s}, 6 \mathrm{H}, \mathrm{C}_{5} M e_{4}\right), 3.70(\mathrm{dd}, 2$ $\left.\mathrm{H},{ }^{2} \mathrm{~J}=8 \mathrm{~Hz},{ }^{3} \mathrm{~J}=2 \mathrm{~Hz}, \mathrm{O}_{2} \mathrm{C}_{2} H_{4}\right), 4.67\left(\mathrm{dd}, 2 \mathrm{H},{ }^{2} \mathrm{~J}=8 \mathrm{~Hz},{ }^{3} \mathrm{~J}=\right.$ $\left.2 \mathrm{~Hz}, \mathrm{O}_{2} \mathrm{C}_{2} H_{4}\right) ;{ }^{13} \mathrm{C}-\mathrm{NMR}\left(\mathrm{C}_{6} \mathrm{D}_{6}\right): 0.1(\mathrm{SiMe}), 10.7,11.9,13.7$ and $13.9\left(\mathrm{C}_{5} M e_{4}\right), 44.7$ (Me-Ti), $74.3\left(\mathrm{O}_{2} \mathrm{C}_{2} \mathrm{H}_{4}\right), 116.6,126.0,127.4$, 128.8 and $130.8\left(C_{5} \mathrm{Me}_{4}\right)$.

$\left[(\mathrm{TiMe})_{2}\left(\boldsymbol{\mu}-1,2-\mathrm{O}_{2} \mathrm{C}_{6} \mathrm{H}_{4}\right)\left(\boldsymbol{\mu}-\left\{\left(\eta^{5}-\mathrm{C}_{5} \mathrm{Me}_{4} \mathrm{SiMeO}\right)_{2}(\boldsymbol{\mu}-\mathrm{O})\right\}\right)\right] \quad(2 \mathrm{~b})$. The same procedure described aboved for $\mathbf{2 a}$ was applied by using 1 b $(0.30 \mathrm{~g}, 0.46 \mathrm{mmol})$ and LiMe (1.5 M, $0.60 \mathrm{~mL}, 0.92 \mathrm{mmol})$ to give $\mathbf{2 b}$ as a yellow solid $(0.22 \mathrm{~g}, 80 \%)$. Data for $\mathbf{2 b}$ : ${ }^{1} \mathrm{H}-\mathrm{NMR}$ $\left(\mathrm{C}_{6} \mathrm{D}_{6}\right): 0.43$ (s, $\left.6 \mathrm{H}, \mathrm{Si} M e\right), 1.03$ (s, $\left.6 \mathrm{H}, M e-\mathrm{Ti}\right), 1.64$ (s, $6 \mathrm{H}$, $\left.\mathrm{C}_{5} M e_{4}\right), 2.02\left(\mathrm{~s}, 6 \mathrm{H}, \mathrm{C}_{5} M e_{4}\right), 2.16\left(\mathrm{~s}, 12 \mathrm{H}, \mathrm{C}_{5} M e_{4}\right), 6.74(\mathrm{~m}$, $\left.2 \mathrm{H}, \mathrm{O}_{2} \mathrm{C}_{6} H_{4}\right), 6.82\left(\mathrm{~m}, 2 \mathrm{H}, \mathrm{O}_{2} \mathrm{C}_{6} H_{4}\right) ;{ }^{13} \mathrm{C}-\mathrm{NMR}\left(\mathrm{C}_{6} \mathrm{D}_{6}\right):-0.1$ (SiMe), 10.7, 11.9, 12.6 and $14.0\left(\mathrm{C}_{5} \mathrm{Me}_{4}\right), 48.7$ (Me-Ti), 117.3, 129.1, 129.5, 130.2 and $131.0\left(C_{5} \mathrm{Me}_{4}\right), 120.2,121.5$ and $155.3\left(C_{i}\right)$ $\left(\mathrm{O}_{2} \mathrm{C}_{6} \mathrm{H}_{4}\right)$. Anal. Calcd for $\mathrm{C}_{28} \mathrm{H}_{40} \mathrm{O}_{5} \mathrm{Si}_{2} \mathrm{Ti}_{2}$ (607.72): C, 55.28; $\mathrm{H}$, $6.58 \%$. Found: C, 54.67; H, 5.84\%.

$\left[(\mathrm{TiBz})_{2}\left(\boldsymbol{\mu}-\mathbf{1 , 2 - \mathrm { O } _ { 2 }} \mathrm{C}_{2} \mathrm{H}_{4}\right)\left(\boldsymbol{\mu}-\left\{\left(\eta^{5}-\mathrm{C}_{5} \mathrm{Me}_{4} \mathrm{SiMeO}\right)_{2}(\boldsymbol{\mu}-\mathrm{O})\right\}\right)\right] \quad$ (3a). $\mathrm{BzMgCl}(2 \mathrm{M}, 1.66 \mathrm{~mL}, 3.32 \mathrm{mmol})$ was injected to a solution of $1 \mathrm{a}(1.00 \mathrm{~g}, 1.66 \mathrm{mmol})$ in diethyl ether $(50 \mathrm{~mL})$ at $-78{ }^{\circ} \mathrm{C}$. The reaction mixture was warmed to room temperature and stirred overnight. $10 \mathrm{~mL}$ of hexane were added and the solution was filtered. The red residue was extracted again into a mixture of solvents diethyl ether-hexane $(30 \mathrm{~mL} / 20 \mathrm{~mL})$. The volatiles were pumped off and the remaining solid was washed with $10 \mathrm{~mL}$ of hexane to isolate $1 \mathrm{c}$ as a red solid $(0.71 \mathrm{~g}, 60 \%)$. Data for 3a: ${ }^{1} \mathrm{H}-\mathrm{NMR}\left(\mathrm{C}_{6} \mathrm{D}_{6}\right): 0.45$ (s, $\left.6 \mathrm{H}, \mathrm{Si} M e\right), 1.62$ (s, $\left.6 \mathrm{H}, \mathrm{C}_{5} M e_{4}\right), 1.79$ $\left(\mathrm{s}, 6 \mathrm{H}, \mathrm{C}_{5} M e_{4}\right), 1.84\left(\mathrm{~s}, 6 \mathrm{H}, \mathrm{C}_{5} M e_{4}\right), 1.97\left(\mathrm{~d}, 2 \mathrm{H},{ }^{2} J=10 \mathrm{~Hz}\right.$, $\mathrm{PhCH}_{2}-\mathrm{Ti}$ ), 2.10 (d, $\left.2 \mathrm{H},{ }^{2} \mathrm{~J}=10 \mathrm{~Hz}, \mathrm{PhCH}_{2}-\mathrm{Ti}\right), 2.18(\mathrm{~s}, 6 \mathrm{H}$, $\left.\mathrm{C}_{5} M e_{4}\right), 3.51\left(\mathrm{dd}, 2 \mathrm{H},{ }^{2} J=8 \mathrm{~Hz},{ }^{3} J=2 \mathrm{~Hz}, \mathrm{O}_{2} \mathrm{C}_{2} H_{4}\right), 4.05(\mathrm{dd}, 2$ $\left.\mathrm{H},{ }^{2} \mathrm{~J}=8 \mathrm{~Hz},{ }^{3} \mathrm{~J}=2 \mathrm{~Hz}, \mathrm{O}_{2} \mathrm{C}_{2} H_{4}\right), 6.82-7.23\left(\mathrm{~m}, 10 \mathrm{H}, \mathrm{PhCH}_{2} \mathrm{Ti}\right)$; ${ }^{13} \mathrm{C}-\mathrm{NMR}\left(\mathrm{C}_{6} \mathrm{D}_{6}\right):-0.2(\mathrm{SiMe}), 10.5,11.4,13.2$ and $14.1\left(\mathrm{C}_{5} \mathrm{Me}_{4}\right)$, $73.8\left(\mathrm{PhCH}_{2}-\mathrm{Ti}\right), 74.0\left(\mathrm{O}_{2} C_{2} \mathrm{H}_{4}\right), 121.8,127.5,128.9,152.0\left(C_{i}\right)$ $\left(\mathrm{PhCH}_{2} \mathrm{Ti}\right) 117.3,126.1,127.2,130.1$ and $130.9\left(C_{5} \mathrm{Me}_{4}\right)$. Anal. Calcd for $\mathrm{C}_{36} \mathrm{H}_{48} \mathrm{O}_{5} \mathrm{Si}_{2} \mathrm{Ti}_{2}$ (711.67): C, 60.70; H, 6.74\%. Found: $\mathrm{C}$, $60.94 ; \mathrm{H}, 6.62 \%$.

$\left[(\mathrm{TiBz})_{2}\left(\boldsymbol{\mu}-\mathbf{1}, 2-\mathrm{O}_{2} \mathrm{C}_{6} \mathrm{H}_{4}\right)\left(\boldsymbol{\mu}-\left\{\left(\boldsymbol{\eta}^{5}-\mathrm{C}_{5} \mathrm{Me}_{4} \mathrm{SiMeO}\right)_{2}(\boldsymbol{\mu}-\mathrm{O})\right\}\right)\right] \quad$ (3b). The same procedure described above for 3a was applied by using 1 b (0.40 g, $0.61 \mathrm{mmol})$ and $\mathrm{MgClBz}(2 \mathrm{M}, 0.62 \mathrm{~mL}, 1.22 \mathrm{mmol})$ to give $3 \mathbf{b}$ as an orange solid $(0.28 \mathrm{~g}, 60 \%)$. Data for $\mathbf{3 b}:{ }^{1} \mathrm{H}-\mathrm{NMR}$ $\left(\mathrm{C}_{6} \mathrm{D}_{6}\right): 0.42$ (s, $\left.6 \mathrm{H}, \mathrm{Si} M e\right), 1.49\left(\mathrm{~s}, 6 \mathrm{H}, \mathrm{C}_{5} M e_{4}\right), 1.59(\mathrm{~s}, 6 \mathrm{H}$, $\left.\mathrm{C}_{5} M e_{4}\right), 1.88\left(\mathrm{~s}, 6 \mathrm{H}, \mathrm{C}_{5} M e_{4}\right), 2.17\left(\mathrm{~s}, 6 \mathrm{H}, \mathrm{C}_{5} M e_{4}\right), 2.20(\mathrm{~d}, 2 \mathrm{H}$, $\left.{ }^{2} J=10 \mathrm{~Hz}, \mathrm{PhCH} \mathrm{H}_{2}-\mathrm{Ti}\right), 2.26\left(\mathrm{~d}, 2 \mathrm{H},{ }^{2} \mathrm{~J}=10 \mathrm{~Hz}, \mathrm{PhCH}_{2}-\mathrm{Ti}\right), 6.79$ (bs, $\left.4 \mathrm{H}, \mathrm{O}_{2} \mathrm{C}_{6} H_{4}\right), 7.01-7.22\left(\mathrm{~m}, 10 \mathrm{H}, \mathrm{C}_{6} H_{5}\right) ;{ }^{13} \mathrm{C}-\mathrm{NMR}\left(\mathrm{C}_{6} \mathrm{D}_{6}\right)$ : -0.5 (SiMe), 10.6, 11.5, 11.9 and $14.0\left(\mathrm{C}_{5} \mathrm{Me}_{4}\right), 77.5\left(\mathrm{PhCH}_{2} \mathrm{Ti}\right)$, 120.0, 121.3, 122.5, 127.0, 129.2, $149.9\left(C_{i}, \mathrm{PhCH}_{2} \mathrm{Ti}\right)$ and 154.8 $\left(C_{i}, \mathrm{O}_{2} C_{6} \mathrm{H}_{4}\right)\left(C_{6} \mathrm{H}_{5}, \mathrm{O}_{2} C_{6} \mathrm{H}_{4}\right), 120.0,126.1,128.8,130.8$ and 131.8 $\left(C_{5} \mathrm{Me}_{4}\right)$. Anal. Calcd for $\mathrm{C}_{40} \mathrm{H}_{48} \mathrm{O}_{5} \mathrm{Si}_{2} \mathrm{Ti}_{2}$ (759.72): C, 63.18; H, 6.31\%. Found: C, 62.69; H, 5.83\%.

$\left[\left\{\mathrm{Ti}(\mathrm{OiPr})_{2}\right\}_{2}\left(\boldsymbol{\mu}-\left\{\left(\boldsymbol{\eta}^{5}-\mathrm{C}_{5} \mathbf{M e}_{4} \mathrm{SiMeO}\right)_{2}(\boldsymbol{\mu}-\mathrm{O})\right\}\right)\right] \quad$ (4). Toluene $(25 \mathrm{~mL})$ was added to a mixture of $\left[\left(\mathrm{TiCl}_{2}\right)_{2}\left(\mu-\left\{\left(\eta^{5}-\mathrm{C}_{5} \mathrm{Me}_{4}-\right.\right.\right.\right.$ $\left.\left.\left.\mathrm{SiMeO})_{2}(\mu-\mathrm{O})\right\}\right)\right](0.33 \mathrm{~g}, 0.53 \mathrm{mmol})$ and $\mathrm{LiO} i \operatorname{Pr}(0.18 \mathrm{~g}$, $2.65 \mathrm{mmol})$ at $-78{ }^{\circ} \mathrm{C}$. The cooling bath was removed and the reaction mixture was allowed to warm to ambient temperature and further stirred overnight. $10 \mathrm{~mL}$ of hexane was then added and the solution was filtered. The volatiles were pumped off to yield 4 as a yellow solid $(0.29 \mathrm{~g}, 80 \%)$. Data for $4:{ }^{1} \mathrm{H}-\mathrm{NMR}$ $\left(\mathrm{CDCl}_{3}\right): 0.26(\mathrm{~s}, 6 \mathrm{H}, \mathrm{SiMe}), 1.12\left(\mathrm{~m}, 24 \mathrm{H}, \mathrm{Me}_{2} \mathrm{CH}\right), 2.03$ (s, $\left.6 \mathrm{H}, \mathrm{C}_{5} M e_{4}\right), 2.05\left(\mathrm{~s}, 6 \mathrm{H}, \mathrm{C}_{5} M e_{4}\right), 2.21\left(\mathrm{~s}, 6 \mathrm{H}, \mathrm{C}_{5} M e_{4}\right), 2.22(\mathrm{~s}$, $\left.6 \mathrm{H}, \mathrm{C}_{5} \mathrm{Me}_{4}\right), 4.68\left(\mathrm{~m}, 4 \mathrm{H}, \mathrm{Me}_{2} \mathrm{CH}\right) ;{ }^{13} \mathrm{C}-\mathrm{NMR}\left(\mathrm{CDCl}_{3}\right):-0.7$ (SiMe), 11.9, 12.0, 13.7 and $14.0\left(\mathrm{C}_{5} \mathrm{Me}_{4}\right), 25.7\left(\mathrm{Me}_{2} \mathrm{CH}\right), 26.1$, 26.4, 26.5 and $26.7\left(\mathrm{Me}_{2} \mathrm{CH}\right), 118.8,127.6,127.7,129.4$ and 129.7 $\left(C_{5} \mathrm{Me}_{4}\right)$. Anal. Calcd for $\mathrm{C}_{32} \mathrm{H}_{58} \mathrm{O}_{7} \mathrm{Si}_{2} \mathrm{Ti}_{2}$ (705.72): C, 54.41; $\mathrm{H}$, $8.21 \%$. Found: C, 53.86; H, 7.95\%.

$\left[\left\{\mathbf{T i C l}\left(\mathbf{C}_{6} \mathbf{F}_{5}\right)\right\}_{2}\left(\boldsymbol{\mu}-\left\{\left(\boldsymbol{\eta}^{5}-\mathbf{C}_{5} \mathbf{M e}_{4} \mathbf{S i M e O}\right)_{2}(\boldsymbol{\mu}-\mathbf{O})\right\}\right)\right] \quad$ (5). Compounds 1a $(0.040 \mathrm{~g}, 0.06 \mathrm{mmol})$ and $(0.5$ toluene $) \cdot \mathrm{Al}\left(\mathrm{C}_{6} \mathrm{~F}_{5}\right)_{3}$ $(0.038 \mathrm{~g}, 0.06 \mathrm{mmol})$ were stirred in toluene $(2 \mathrm{~mL})$ for $12 \mathrm{~h}$. The solution was filtered and the volatiles were removed under vacuum leaving an oil that was washed with hexane $(2 \times 2 \mathrm{~mL})$ to give 5 as a yellow solid $(0.031 \mathrm{~g}, 60 \%)$. Data for 5: ${ }^{1} \mathrm{H}-\mathrm{NMR}$ $\left(\mathrm{C}_{6} \mathrm{D}_{6}\right) 0.33(\mathrm{~s}, 6 \mathrm{H}, \mathrm{Si} M e), 1.98\left(\mathrm{~s}, 6 \mathrm{H}, \mathrm{C}_{5} M e_{4}\right), 2.04(\mathrm{~s}, 6 \mathrm{H}$, $\mathrm{C}_{5} \mathrm{Me}_{4}$ ), 2.15 (s, $\left.6 \mathrm{H}, \mathrm{C}_{5} M e_{4}\right), 2.39$ (s, $\left.6 \mathrm{H}, \mathrm{C}_{5} M e_{4}\right) ;{ }^{13} \mathrm{C}-\mathrm{NMR}$ $\left(\mathrm{C}_{6} \mathrm{D}_{6}\right):-2.0(\mathrm{Si} M e), 12.8,13.3,15.1$ and $15.9\left(\mathrm{C}_{5} M e_{4}\right), 119.3$, 138.7, 139.1, 141.3 and $144.7\left(C_{5} \mathrm{Me}_{4}\right), 139.2,145.4$ and 150.1 $\left(\mathrm{m}, C_{6} \mathrm{~F}_{5}\right) ;{ }^{19} \mathrm{~F}-\mathrm{NMR}\left(\mathrm{C}_{6} \mathrm{D}_{6}\right):-120.1\left(\mathrm{o}-\mathrm{C}_{6} F_{5}\right),-153.4\left(\mathrm{p}-\mathrm{C}_{6} F_{5}\right)$, $-162.3\left(\mathrm{~m}-\mathrm{C}_{6} F_{5}\right)$. Anal. Calcd for $\mathrm{C}_{32} \mathrm{H}_{30} \mathrm{O}_{3} \mathrm{Si}_{2} \mathrm{Ti}_{2} \mathrm{Cl}_{2} \mathrm{~F}_{10}$ (874.50): C, 43.91; H, 3.43\%. Found: C, 43.99; H, 4.11\%.

Reaction of $1 \mathrm{~b}$ with $\mathrm{Al}\left(\mathrm{C}_{6} \mathrm{~F}_{5}\right)_{3}$. Formation of $\left[(\mathrm{TiCl})_{2}(\boldsymbol{\mu}-1\right.$, 2- $\left.\left.\mathrm{O}_{2} \mathrm{C}_{6} \mathrm{H}_{4}\right)\left\{\boldsymbol{\mu}-\left(\left\{\boldsymbol{\eta}^{5}-\mathrm{C}_{5} \mathrm{Me}_{4} \mathrm{SiMeO}\right\}_{2}\left\{\boldsymbol{\mu}-\mathrm{O} \cdot \mathrm{Al}\left(\mathrm{C}_{6} \mathrm{~F}_{5}\right)_{3}\right\}\right)\right\}\right](6)$ and I ( TiCl $)\left\{\mathrm{Ti}\left(\mathrm{C}_{6} \mathrm{~F}_{5}\right)\right\}\left(\mu-1,2-\mathrm{O}_{2} \mathrm{C}_{6} \mathrm{H}_{4}\right)\left(\mu-\left\{\left(\eta^{5}-\mathrm{C}_{5} \mathrm{Me}_{4} \mathrm{SiMeO}\right)_{2}\right.\right.$ $(\boldsymbol{\mu}-\mathrm{O})\})]$ (7). A solution of $\left[(\mathrm{TiCl})_{2}\left(\mu-1,2-\mathrm{O}_{2} \mathrm{C}_{6} \mathrm{H}_{4}\right)\left(\mu-\left\{\left(\eta^{5}-\right.\right.\right.\right.$ $\left.\left.\left.\left.\mathrm{C}_{5} \mathrm{Me}_{4} \mathrm{SiMeO}\right)_{2}(\mu-\mathrm{O})\right\}\right)\right]$ (1b) $(0.020 \mathrm{~g}, 0.03 \mathrm{mmol})$ in $\mathrm{C}_{6} \mathrm{D}_{6}$ in a NMR tube was treated with one equivalent of 0.5 (toluene $) \cdot \mathrm{Al}\left(\mathrm{C}_{6} \mathrm{~F}_{5}\right)_{3}(0.017 \mathrm{~g}, 0.03 \mathrm{mmol})$. The reaction was immediately monitored by NMR spectroscopy, showing a complete transformation into $\mathbf{6}$ after $5 \mathrm{~min}$. The solution of $\mathbf{6}$ evolved to a mixture of 7 and 5 in ca. 2: 1 after two days at ambient temperature. Data for 6: ${ }^{1} \mathrm{H}-\mathrm{NMR}\left(\mathrm{C}_{6} \mathrm{D}_{6}\right): 0.31(\mathrm{~s}, 6 \mathrm{H}, \mathrm{Si} M e), 1.64(\mathrm{~s}, 6 \mathrm{H}$, $\left.\mathrm{C}_{5} M e_{4}\right), 1.84\left(\mathrm{~s}, 6 \mathrm{H}, \mathrm{C}_{5} M e_{4}\right), 2.03\left(\mathrm{~s}, 6 \mathrm{H}, \mathrm{C}_{5} M e_{4}\right), 2.19(\mathrm{~s}, 6 \mathrm{H}$, $\left.\mathrm{C}_{5} \mathrm{Me}_{4}\right), 6.65\left(\mathrm{~m}, 2 \mathrm{H}, \mathrm{O}_{2} \mathrm{C}_{6} \mathrm{H}_{4}\right), 6.78\left(\mathrm{~m}, 2 \mathrm{H}, \mathrm{O}_{2} \mathrm{C}_{6} \mathrm{H}_{4}\right) ;{ }^{13} \mathrm{C}-\mathrm{NMR}$ $\left(\mathrm{C}_{6} \mathrm{D}_{6}\right)$ : -1.7 (SiMe), 10.9, 12.6, 13.1 and $14.1\left(\mathrm{C}_{5} M e_{4}\right), 119.9$, 123.9 and $154.9\left(C_{i}\right)\left(\mathrm{O}_{2} C_{6} \mathrm{H}_{4}\right), 122.3,132.4,135.2,137.8,141.1$ $\left(C_{5} \mathrm{Me}_{4}\right), 137.2,141.3$ and $150.9\left(\mathrm{~m}, C_{6} \mathrm{~F}_{5}\right) ;{ }^{19} \mathrm{~F}-\mathrm{NMR}\left(\mathrm{C}_{6} \mathrm{D}_{6}\right)$ : $-121.1\left(\mathrm{o}-\mathrm{C}_{6} F_{5}\right),-151.2\left(\mathrm{p}-\mathrm{C}_{6} F_{5}\right),-160.7\left(\mathrm{~m}-\mathrm{C}_{6} F_{5}\right)$. Data for 7: ${ }^{1} \mathrm{H}-\mathrm{NMR}\left(\mathrm{C}_{6} \mathrm{D}_{6}\right)$ : 0.40 (s, $\left.3 \mathrm{H}, \mathrm{SiMe}\right), 0.48$ (s, $\left.3 \mathrm{H}, \mathrm{SiMe}\right), 1.40$ (s, $\left.3 \mathrm{H}, \mathrm{C}_{5} M e_{4}\right), 1.69$ (s, $\left.3 \mathrm{H}, \mathrm{C}_{5} M e_{4}\right), 1.71\left(\mathrm{~s}, 3 \mathrm{H}, \mathrm{C}_{5} M e_{4}\right), 1.93$ (s, 3 $\left.\mathrm{H}, \mathrm{C}_{5} M e_{4}\right), 2.03\left(\mathrm{~s}, 3 \mathrm{H}, \mathrm{C}_{5} M e_{4}\right), 2.19\left(\mathrm{~s}, 3 \mathrm{H}, \mathrm{C}_{5} M e_{4}\right), 2.25$ (s, 3 $\left.\mathrm{H}, \mathrm{C}_{5} M e_{4}\right), 2.26\left(\mathrm{~s}, 3 \mathrm{H}, \mathrm{C}_{5} M e_{4}\right), 6.95-7.23\left(\mathrm{~m}, 4 \mathrm{H}, \mathrm{O}_{2} \mathrm{C}_{6} H_{4}\right)$; 


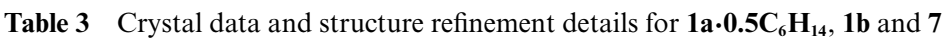

\begin{tabular}{|c|c|c|c|}
\hline & $1 \mathrm{a} \cdot 0.5 \mathrm{C}_{6} \mathrm{H}_{14}$ & 1b & 7 \\
\hline $\begin{array}{l}\text { Formula } \\
\text { FW }\end{array}$ & $\mathrm{C}_{25} \mathrm{H}_{41} \mathrm{Cl}_{2} \mathrm{O}_{5} \mathrm{Si}_{2} \mathrm{Ti}_{2}$ & $\mathrm{C}_{26} \mathrm{H}_{34} \mathrm{Cl}_{2} \mathrm{O}_{5} \mathrm{Si}_{2} \mathrm{Ti}_{2}$ & $\mathrm{C}_{32} \mathrm{H}_{34} \mathrm{ClF}_{5} \mathrm{O}_{5} \mathrm{Si}_{2} \mathrm{Ti}_{2}$ \\
\hline $\begin{array}{l}\text { FW } \\
\text { Color/habit }\end{array}$ & $\begin{array}{l}644.46 \\
\text { Yellow/block }\end{array}$ & $\begin{array}{l}649.41 \\
\text { Red/prism }\end{array}$ & $\begin{array}{l}781.02 \\
\text { Orange/prism }\end{array}$ \\
\hline Cryst. dimensions $/ \mathrm{mm}$ & $0.48 \times 0.43 \times 0.36$ & $0.49 \times 0.35 \times 0.31$ & $0.45 \times 0.20 \times 0.10$ \\
\hline Cryst. syst. & Monoclinic & Monoclinic & Monoclinic \\
\hline Space group & $P 2_{1} / c$ & $P 2_{1} / c$ & $P 2_{1} / c$ \\
\hline$a / \AA$ & $17.207(5)$ & $14.112(3)$ & $11.597(4)$ \\
\hline$b / \AA ̊$ & $11.438(3)$ & $10.4098(7)$ & $17.888(3)$ \\
\hline$c / \AA$ & $17.691(3)$ & $21.228(3)$ & $16.826(5)$ \\
\hline$\beta /^{\circ}$ & $116.591(10)$ & $104.083(14)$ & $95.61(2)$ \\
\hline$V / \AA^{3}$ & $3113.5(14)$ & $3024.7(8)$ & $3473.8(15)$ \\
\hline$Z$ & 4 & 4 & 4 \\
\hline$T / \mathrm{K}$ & 200 & 200 & 200 \\
\hline$\rho_{\mathrm{c}} / \mathrm{g} \mathrm{cm}^{-3}$ & 1.375 & 1.426 & 1.493 \\
\hline$\mu / \mathrm{mm}^{-1}$ & 0.793 & 0.817 & 0.671 \\
\hline$F(000)$ & 1348 & 1344 & 1600 \\
\hline$\theta$ range $/^{\circ}$ & $3.56-27.51$ & $3.15-27.50$ & $3.53-27.50$ \\
\hline no. of rflns collected & 67211 & 21976 & 70795 \\
\hline no. of indep. rflns $/ R_{\text {int }}$ & $7118 / 0.0667$ & $6948 / 0.0674$ & $7957 / 0.1090$ \\
\hline no. of obsd rflns $(I>2 \sigma(I))$ & 5599 & 4787 & 4936 \\
\hline$R_{1}, \mathrm{w} R_{2}(I>2 \sigma(I))^{\mathrm{a}}$ & $0.0646 / 0.1616$ & $0.0441 / 0.1067$ & $0.0583 / 0.1427$ \\
\hline$R_{1}, \mathrm{w} R_{2}(\text { all data })^{\mathrm{a}}$ & $0.0799 / 0.1711$ & $0.0808 / 0.1184$ & $0.1132 / 0.1613$ \\
\hline Extinction coefficient & $0.058(3)$ & & $0.0080(9)$ \\
\hline $\mathrm{GOF}\left(\text { on } F^{2}\right)^{\mathrm{a}}$ & 1.089 & 1.039 & 1.046 \\
\hline Largest diff. peak/hole/e $\AA^{-3}$ & $+0.664 /-0.617$ & $0.549 /-0.437$ & $+0.495 /-0.539$ \\
\hline
\end{tabular}

${ }^{19} \mathrm{~F}-\mathrm{NMR}\left(\mathrm{C}_{6} \mathrm{D}_{6}\right):-114.7\left(\mathrm{o}-\mathrm{C}_{6} F_{5}\right),-154.3\left(\mathrm{p}-\mathrm{C}_{6} F_{5}\right),-162.1$ $\left(\mathrm{m}-\mathrm{C}_{6} F_{5}\right)$.

$\left[\mathrm{Ti}(\mathrm{TiBz})\left(\mu-1,2-\mathrm{O}_{2} \mathrm{C}_{2} \mathrm{H}_{4}\right)\left(\mu-\left\{\left(\eta^{5}-\mathrm{C}_{5} \mathrm{Me}_{4} \mathrm{SiMeO}\right)_{2}(\mu-\mathrm{O})\right\}\right)\right][\mathrm{BzB}-$ $\left.\left(\mathbf{C}_{6} \mathbf{F}_{5}\right)_{3} \mathbf{3} \mathbf{( 8 B}\right)$. A solution of $\mathbf{3 a}(0.100 \mathrm{~g}, 0.14 \mathrm{mmol})$ and $\mathrm{B}\left(\mathrm{C}_{6} \mathrm{~F}_{5}\right)_{3}$ $(0.071 \mathrm{~g}, 0.14 \mathrm{mmol})$ in $\mathrm{CH}_{2} \mathrm{Cl}_{2}(2 \mathrm{~mL})$ were stirred for $5 \mathrm{~min}$. The volatiles were removed under vacuum leaving an oil that was washed with hexane $(2 \times 2 \mathrm{~mL})$ to give $\mathbf{8 B}$ as an orange solid $(0.146 \mathrm{~g}, 85 \%)$. Data for 8B: ${ }^{1} \mathrm{H}-\mathrm{NMR}\left(\mathrm{CD}_{2} \mathrm{Cl}_{2}\right): 0.47(\mathrm{~s}, 3 \mathrm{H}$, $\mathrm{SiMe}$ ), 0.54 (s, $3 \mathrm{H}, \mathrm{Si} M e$ ), 1.77 (s, $3 \mathrm{H}, \mathrm{C}_{5} M e_{4}$ ), 1.84 (s, $3 \mathrm{H}$, $\left.\mathrm{C}_{5} M e_{4}\right), 2.05\left(\mathrm{~s}, 3 \mathrm{H}, \mathrm{C}_{5} M e_{4}\right), 2.09\left(\mathrm{~s}, 3 \mathrm{H}, \mathrm{C}_{5} M e_{4}\right), 2.26(\mathrm{~s}, 3 \mathrm{H}$, $\left.\mathrm{C}_{5} M e_{4}\right), 2.27\left(\mathrm{~s}, 3 \mathrm{H}, \mathrm{C}_{5} M e_{4}\right), 2.34\left(\mathrm{~s}, 6 \mathrm{H}, \mathrm{C}_{5} M e_{4}\right), 2.71(\mathrm{~d}, 1$ $\mathrm{H},{ }^{2} \mathrm{~J}=12 \mathrm{~Hz}, \mathrm{PhCH}_{2}$-Ti), 2.77 (bs, $2 \mathrm{H}, \mathrm{PhCH}_{2}$-B), 3.15 (d, 1 $\left.\mathrm{H},{ }^{2} \mathrm{~J}=12 \mathrm{~Hz}, \mathrm{PhCH}_{2}-\mathrm{Ti}\right), 3.40\left(\mathrm{~m}, 1 \mathrm{H}, \mathrm{O}_{2} \mathrm{C}_{2} H_{4}\right), 3.70(\mathrm{~m}, 2$ $\left.\mathrm{H}, \mathrm{O}_{2} \mathrm{C}_{2} H_{4}\right), 4.25\left(\mathrm{~m}, 1 \mathrm{H}, \mathrm{O}_{2} \mathrm{C}_{2} H_{4}\right), 6.70-7.26\left(\mathrm{~m}, 10 \mathrm{H}, \mathrm{C}_{6} H_{5}\right)$; ${ }^{13} \mathrm{C}-\mathrm{NMR}\left(\mathrm{CD}_{2} \mathrm{Cl}_{2}\right):-1.5(\mathrm{SiMe}),-0.8(\mathrm{SiMe}), 12.1,12.4,13.2$, 13.5, 15.1, 15.9, 16.3 and $17.0\left(\mathrm{C}_{5} M_{4}\right), 31.9\left(\mathrm{PhCH}_{2}-\mathrm{B}\right), 68.8$ and $77.4\left(\mathrm{O}_{2} C_{2} \mathrm{H}_{4}\right), 95.0\left(\mathrm{PhCH}_{2}-\mathrm{Ti}\right), 121.9\left(C_{i}\right), 122.7,126.2\left(C_{i}\right)$, $126.4\left(C_{i}\right), 126.5,126.8,127.0,128.7\left(C_{i}\right), 128.9,129.3,129.9$, $131.7\left(C_{i}\right), 135.8\left(C_{i}\right), 137.4\left(C_{i}\right), 138.3\left(C_{i}\right), 141.3\left(C_{i}\right), 141.40$ $\left(C_{i}\right), 149.24\left(C_{i}\right), 151.03\left(C_{i}\right)\left(P h \mathrm{CH}_{2}-\mathrm{B}, C_{5} \mathrm{Me}_{4}, P h \mathrm{CH}_{2}-\mathrm{Ti}\right) ;{ }^{19} \mathrm{~F}-$ NMR $\left(\mathrm{CD}_{2} \mathrm{Cl}_{2}\right)$ : -127.9 (o- $\left.\mathrm{C}_{6} F_{5}\right),-161.5\left(\mathrm{p}-\mathrm{C}_{6} F_{5}\right),-164.4(\mathrm{~m}-$ $\mathrm{C}_{6} F_{5}$ ). Anal. Calcd for $\mathrm{C}_{54} \mathrm{H}_{48} \mathrm{O}_{5} \mathrm{Si}_{2} \mathrm{Ti}_{2} \mathrm{BF}_{15}$ (1223.20): C, 52.96; $\mathrm{H}$, $3.92 \%$. Found: C, 53.50; H, 4.21\%.

$\left[\mathrm{Ti}(\mathrm{TiBz})\left(\boldsymbol{\mu}-1,2-\mathrm{O}_{2} \mathrm{C}_{2} \mathrm{H}_{4}\right)\left(\boldsymbol{\mu}-\left\{\left(\eta^{5}-\mathrm{C}_{5} \mathrm{Me}_{4} \mathrm{SiMeO}\right)_{2}(\mu-\mathrm{O})\right\}\right)\right]-$ $\left.\left[\mathbf{B z A l}\left(\mathbf{C}_{6} \mathbf{F}_{5}\right)_{3}\right] \mathbf{( 8 A l}\right)$. Compounds 3a $(0.020 \mathrm{~g}, 0.02 \mathrm{mmol})$ and 0.5 (toluene) $\cdot \mathrm{Al}\left(\mathrm{C}_{6} \mathrm{~F}_{5}\right)_{3}(0.032 \mathrm{~g}, 0.04 \mathrm{mmol})$ were loaded into a NMR tube and $0.5 \mathrm{~mL}$ of $\mathrm{CD}_{2} \mathrm{Cl}_{2}$ was added. The tube was then shaken vigorously and the reaction was monitored by NMR spectroscopy at $25^{\circ} \mathrm{C}$, formation of $\mathbf{8 A l}$ occurred immediately. Data for 8Al: ${ }^{1} \mathrm{H}-\mathrm{NMR}\left(\mathrm{CD}_{2} \mathrm{Cl}_{2}\right): 0.62$ (s, $\left.3 \mathrm{H}, \mathrm{SiMe}\right), 0.69$ (s, 3 $\mathrm{H}, \mathrm{SiMe}), 1.36\left(\mathrm{~s}, 3 \mathrm{H}, \mathrm{C}_{5} M e_{4}\right), 1.71\left(\mathrm{~s}, 3 \mathrm{H}, \mathrm{C}_{5} M e_{4}\right), 2.00(\mathrm{~s}, 3 \mathrm{H}$, $\left.\mathrm{C}_{5} M e_{4}\right), 2.06\left(\mathrm{~s}, 3 \mathrm{H}, \mathrm{C}_{5} M e_{4}\right), 2.24\left(\mathrm{~s}, 3 \mathrm{H}, \mathrm{C}_{5} M e_{4}\right), 2.32(\mathrm{~s}, 3 \mathrm{H}$,
$\left.\mathrm{C}_{5} \mathrm{Me}_{4}\right), 2.36\left(\mathrm{~s}, 3 \mathrm{H}, \mathrm{C}_{5} \mathrm{Me}_{4}\right), \mathrm{PhCH}_{2}-\mathrm{Al}$ was not observed, 2.47 (d, $\left.1 \mathrm{H},{ }^{2} \mathrm{~J}=12 \mathrm{~Hz}, \mathrm{PhCH} \mathrm{H}_{2} \mathrm{Ti}\right), 2.89\left(\mathrm{~s}, 3 \mathrm{H}, \mathrm{C}_{5} \mathrm{Me}_{4}\right), 3.36\left(\mathrm{~d}, 1 \mathrm{H},{ }^{2} \mathrm{~J}=\right.$ $\left.12 \mathrm{~Hz}, \mathrm{PhCH} \mathrm{H}_{2}-\mathrm{Ti}\right), 3.79\left(\mathrm{~m}, 1 \mathrm{H}, \mathrm{O}_{2} \mathrm{C}_{2} H_{4}\right), 3.91\left(\mathrm{~m}, 1 \mathrm{H}, \mathrm{O}_{2} \mathrm{C}_{2} H_{4}\right)$, $4.62\left(\mathrm{~m}, 2 \mathrm{H}, \mathrm{O}_{2} \mathrm{C}_{2} H_{4}\right), 6.81-7.42\left(\mathrm{~m}, 10 \mathrm{H}, \mathrm{C}_{6} H_{5}\right) ;{ }^{13} \mathrm{C}-\mathrm{NMR}$ $\left(\mathrm{CD}_{2} \mathrm{Cl}_{2}\right)$ : $-2.0(\mathrm{Si} M e),-1.9(\mathrm{Si} M e), 11.5,12.3,12.6,12.9,13.8$, 15.9, 16.4 and $16.6\left(\mathrm{C}_{5} M e_{4}\right), \mathrm{PhCH}_{2}-\mathrm{Al}$ was not observed, 67.2 and $75.2\left(\mathrm{O}_{2} C_{2} \mathrm{H}_{4}\right), 99.4\left(\mathrm{PhCH}_{2}-\mathrm{Ti}\right), 120.6\left(C_{i}\right), 121.7\left(C_{i}\right), 126.8$, $126.9\left(C_{i}\right), 127.4,127.5\left(C_{i}\right), 127.8\left(C_{i}\right), 129.8,129.8\left(C_{i}\right), 130.2$, $130.2\left(C_{i}\right)$ and $133.3\left(P_{C H} \mathrm{CH}_{2}-\mathrm{Al}, C_{5} \mathrm{Me}_{4}, P h \mathrm{CH}_{2}-\mathrm{Ti}\right) ;{ }^{19} \mathrm{~F}-\mathrm{NMR}$ $\left(\mathrm{CD}_{2} \mathrm{Cl}_{2}\right):-120.1\left(\mathrm{o}-\mathrm{C}_{6} F_{5}\right),-155.8\left(\mathrm{p}-\mathrm{C}_{6} F_{5}\right),-161.7\left(\mathrm{~m}-\mathrm{C}_{6} F_{5}\right)$.

$\left[\mathrm{Ti}(\mathrm{TiBz})\left(\boldsymbol{\mu}-1,2-\mathrm{O}_{2} \mathrm{C}_{6} \mathrm{H}_{4}\right)\left(\boldsymbol{\mu}-\left\{\left(\boldsymbol{\eta}^{5}-\mathrm{C}_{5} \mathrm{Me}_{4} \mathrm{SiMeO}\right)_{2}(\boldsymbol{\mu}-\mathrm{O})\right\}\right)\right][\mathrm{BzB}-$ $\left.\left(\mathbf{C}_{6} \mathbf{F}_{5}\right)_{3}\right](\mathbf{9 B}) . \quad 0.5 \mathrm{~mL}$ of $\mathrm{CD}_{2} \mathrm{Cl}_{2}$ previously cooled at $-78{ }^{\circ} \mathrm{C}$ were added to a mixture of $\mathbf{3 b}(0.030 \mathrm{~g}, 0.03 \mathrm{mmol})$ and $\mathrm{B}\left(\mathrm{C}_{6} \mathrm{~F}_{5}\right)_{3}$ $(0.025 \mathrm{~g}, 0.03 \mathrm{mmol})$ in a NMR tube cooled at $-78^{\circ} \mathrm{C}$. The NMR spectra, run at $-20^{\circ} \mathrm{C}$, showed formation of $9 \mathrm{~B}$ as the only product. Data for 9B: ${ }^{1} \mathrm{H}-\mathrm{NMR}\left(\mathrm{CD}_{2} \mathrm{Cl}_{2}\right): 0.26(\mathrm{~s}, 3 \mathrm{H}, \mathrm{Si} M e), 0.37$ (s, 3 $\mathrm{H}, \mathrm{Si} M e), 1.42\left(\mathrm{~s}, 3 \mathrm{H}, \mathrm{C}_{5} M e_{4}\right), 1.47\left(\mathrm{~s}, 3 \mathrm{H}, \mathrm{C}_{5} M e_{4}\right), 1.91(\mathrm{~s}, 3 \mathrm{H}$, $\left.\mathrm{C}_{5} \mathrm{Me}_{4}\right), 1.93\left(\mathrm{~s}, 3 \mathrm{H}, \mathrm{C}_{5} M e_{4}\right), 2.12\left(\mathrm{~s}, 3 \mathrm{H}, \mathrm{C}_{5} M e_{4}\right), 2.17$ (bs, $1 \mathrm{H}$, $\mathrm{PhCH}_{2}-\mathrm{Ti}$ ), 2.24 (s, $3 \mathrm{H}, \mathrm{C}_{5} \mathrm{Me}_{4}$ ), 2.29 (s, $3 \mathrm{H}, \mathrm{C}_{5} \mathrm{Me}_{4}$ ), 2.41 (bs, $2 \mathrm{H}, \mathrm{PhCH}_{2}$-Ti), 2.46 (s, $3 \mathrm{H}, \mathrm{C}_{5} \mathrm{Me}_{4}$ ), 2.71 (bs, $1 \mathrm{H}, \mathrm{PhCH}_{2}-$ B), 6.70-7.20 (m, $\left.10 \mathrm{H}, \mathrm{C}_{6} H_{5}, \mathrm{O}_{2} \mathrm{C}_{6} H_{4}\right) ;{ }^{13} \mathrm{C}-\mathrm{NMR}\left(\mathrm{CD}_{2} \mathrm{Cl}_{2}\right)$ : -2.1 (SiMe), -2.0 (SiMe), 11.2, 12.4, 13.1, 13.8, 14.7, 15.2, 15.8 and $16.6\left(\mathrm{C}_{5} \mathrm{Me}_{4}\right), 38.4\left(\mathrm{PhCH}_{2}-\mathrm{B}\right), 80.2\left(\mathrm{PhCH}_{2}-\mathrm{Ti}\right), 120.1-$ $140.3\left(C_{6} \mathrm{H}_{5}, C_{6} \mathrm{~F}_{5}, \mathrm{O}_{2} C_{6} \mathrm{H}_{4}, C_{5} \mathrm{Me}_{4}\right) ;{ }^{19} \mathrm{~F}-\mathrm{NMR}\left(\mathrm{CD}_{2} \mathrm{Cl}_{2}\right):-133.1$ $\left(\mathrm{o}-\mathrm{C}_{6} F_{5}\right),-158.4\left(\mathrm{p}-\mathrm{C}_{6} F_{5}\right),-163.8\left(\mathrm{~m}-\mathrm{C}_{6} F_{5}\right)$.

Polymerization of E-caprolactone with dinuclear complex 4. $\varepsilon$-Caprolactone ( $1 \mathrm{~g}$ ) was added via syringe to a stirred solution of complex $4(0.04 \mathrm{mmol})$ in toluene $(5 \mathrm{~mL})$, in a glove box. The polymerization mixture was stirred at the desired temperature. After the measured time interval, the flask was quenched by adding $5 \mathrm{~mL}$ of $\mathrm{MeOH}-\mathrm{HCl}$ diluted. The quenched mixture was precipitated into $150 \mathrm{~mL}$ of methanol, stirred overnight, filtered, 
and washed with methanol. The polymer collected was dissolved in acetone, precipitated in methanol at $0{ }^{\circ} \mathrm{C}$, filtered, and dried in a vacuum oven at $80{ }^{\circ} \mathrm{C}$. A ${ }^{1} \mathrm{H}$ NMR $\left(\mathrm{CDCl}_{3}\right)$ spectrum of the polymer was obtained for an end group analysis. Gel permeation chromatography (GPC) analyses of polymer samples were carried out in THF as solvent at $25^{\circ} \mathrm{C}$ (Varian HPLC) in Alcalá University.

Polymerization of E-caprolactone with mononuclear complex [TiCp*(OiPr) $)_{3}$ ](E). Polymerization was carried out as described above except a toluene solution of $\mathbf{E}(0.08 \mathrm{mmol})$ was used with the aim of introducing an equal number of metal centers into the solution in each experiment.

\section{$\mathrm{X}$-Ray structure determination of $1 \mathrm{a} \cdot 0.5 \mathrm{C}_{6} \mathrm{H}_{14}, 1 \mathrm{~b}$ and 7}

Suitable single crystals of $\mathbf{1 a \cdot 0 . 5 C _ { 6 }} \mathbf{H}_{\mathbf{1 4}}, \mathbf{1 b}$ and $\mathbf{7}$ for the $\mathrm{X}$-ray diffraction study were selected. Data collection for was performed at 200(2) K, with the crystals covered in perfluorinated ether. The crystals were mounted on a Bruker-Nonius Kappa CCD single crystal diffractometer equipped with a graphitemonochromated Mo-K $\alpha$ radiation $\left(\lambda=0.71073 \AA\right.$ ). Multiscan ${ }^{49}$ absorption correction procedures were applied to the data. The structures were solved, using the WINGX package, ${ }^{50}$ by direct methods (SHELXS-97) and refined by using full-matrix leastsquares against $\mathrm{F}^{2}$ (SHELXL-97). ${ }^{51}$ All non-hydrogen atoms were anisotropically refined. Hydrogen atoms were geometrically placed and left riding on their parent atoms. Full-matrix leastsquares refinements were carried out by minimizing $\sum \mathrm{w}\left(F_{\mathrm{o}}{ }^{2}-\right.$ $\left.F_{\mathrm{c}}{ }^{2}\right)^{2}$ with the SHELXL-97 weighting scheme and stopped at shift/err $<0.001$. The final residual electron density maps showed no remarkable features. Also in 1a a molecule of hexane crystallized with every two molecules of the compound. This solvent molecule was found in the difference Fourier map but was very disordered and it was not possible to get a chemical sensible model for it, so Squeeze procedure ${ }^{52}$ was used to remove its contribution to the structure factors. Relevant crystallographic data and details of the refinements for the three structures are given in Table 3. CCDC 708809 (1a.0.5C $\left.\mathbf{H}_{\mathbf{1 4}}\right)$, CCDC 708810 (1b) and CCDC 708811 (7) contain the supplementary crystallographic data for this paper. For crystallographic data in CIF or other electronic format see DOI: $10.1039 /$ b820092k

\section{Acknowledgements}

We gratefully acknowledge Ministerio de Educación y Ciencia (project MAT2007-60997) and DGUI-Comunidad de Madrid (programme S-0505/PPQ-0328 COMAL-CM) (Spain) for financial support. L. P. acknowledges DGUI-CM for Fellowship.

\section{References}

1 A. L. Gavrilova and B. Bosnich, Chem. Rev., 2004, 104, 349-383.

2 M. R. Salata and T. J. Marks, J. Am. Chem. Soc., 2008, 130, 12-16.

3 N. Guo, L. T. Li and T. J. Marks, J. Am. Chem. Soc., 2004, 126, 65426543.

4 L. T. Li, M. V. Metz, H. B. Li, M. C. Chen, T. J. Marks, L. Liable-Sands and A. L. Rheingold, J. Am. Chem. Soc., 2002, 124, 12725-12741.

5 Y. X. Chen, M. V. Metz, L. T. Li, C. L. Stern and T. J. Marks, J. Am. Chem. Soc., 1998, 120, 6287-6305.
6 M. H. Lee, S. K. Kim and Y. Do, Organometallics, 2005, 24, 3618 3620.

7 S. K. Noh, J. Lee and D. H. Lee, J. Organomet. Chem., 2003, 667, 53-60.

8 S. K. Noh, J. Kim, J. Jung, C. S. Ra, D.-h. Lee, H. B. Lee, S. W. Lee and W. S. Huh, J. Organomet. Chem., 1999, 580, 90-97.

9 H. G. Alt and R. Ernst, J. Mol. Catal. A: Chem., 2003, 195, 11-27.

10 H. G. Alt and R. Ernst, Inorg. Chim. Acta, 2003, 350, 1-11.

11 H. G. Alt, R. Ernst and I. K. Bohmer, J. Organomet. Chem., 2002, 658, 259-265.

12 G. Stojcevic, H. Kim, N. J. Taylor, T. B. Marder and S. Collins, Angew. Chem., Int. Ed., 2004, 43, 5523-5526.

13 Y. F. Li, D. G. Ward, S. S. Reddy and S. Collins, Macromolecules, 1997, 30, 1875-1883.

14 S. H. Lee, C. J. Wu, U. G. Joung, B. Y. Lee and J. Park, Dalton Trans., 2007, 4608-4614.

15 D. C. Bradley, R. C. Mehrota, I. P. Rothwell, and A. Singh, Alkoxo and Aryloxo Derivatives of Metals, Academic Press: San Diego, CA, 2001.

16 A. D. Asandei, Y. H. Chen, O. I. Adebolu and C. P. Simpson, J. Polym. Sci., Polym. Chem., 2008, 46, 2869-2877.

17 H. E. Dyer, S. Huijser, A. D. Schwarz, C. Wang, R. Duchateau and P. Mountford, Dalton Trans., 2008, 32-35.

18 K. Krauzy-Dziedzic, J. Ejfler, S. Szafert and P. Sobota, Dalton Trans, 2008, 2620-2626.

19 F. Gornshtein, M. Kapon, M. Botoshansky and M. S. Eisen, Organometallics, 2007, 26, 497-507.

20 M. G. Davidson, M. D. Jones, M. D. Lunn and M. F. Mahon, Inorg. Chem., 2006, 45, 2282-2287.

21 Y. Pérez, I. del Hierro, I. Sierra, P. Gómez-Sal, M. Fajardo and A. Otero, J. Organomet. Chem., 2006, 691, 3053-3059.

22 Y. Sarazin, R. H. Howard, D. L. Hughes, S. M. Humphrey and M. Bochmann, Dalton Trans., 2006, 340-350.

23 W. Braune, H. Y. Ma, T. P. Spaniol and J. Okuda, Organometallics, 2005, 24, 1953-1958.

24 D. Santamaría, J. Cano, P. Royo, M. E. G. Mosquera, T. Cuenca, L. M. Frutos and O. Castaño, Angew. Chem., Int. Ed., 2005, 44, 58285830.

25 R. Arteaga-Müller, J. Sánchez-Nieves, P. Royo and M. E. G. Mosquera, Polyhedron, 2005, 24, 1274-1279.

26 O. Buitrago, G. Jiménez and T. Cuenca, J. Organomet. Chem., 2003, 683, 70-76.

27 J. Cano, P. Royo, M. Lanfranchi, M. A. Pellinghelli and A. Tiripicchio, Angew. Chem., Int. Ed., 2001, 40, 2495-2497.

28 S. Ciruelos, A. Sebastián, T. Cuenca, P. Gómez-Sal, A. Manzanero and P. Royo, J. Organomet. Chem., 2000, 604, 103-115.

29 M. I. Alcalde, M. P. Gómez-Sal and P. Royo, Organometallics, 1999, 18, 546-554.

30 F. J. de la Mata, P. Giner and P. Royo, J. Organomet. Chem., 1999, 572, $155-161$.

31 M. I. Alcalde, P. Gómez-Sal, A. Martín and P. Royo, Organometallics, 1998, 17, 1144-1150.

32 S. Ciruelos, T. Cuenca, P. Gómez-Sal, A. Manzanero and P. Royo, Organometallics, 1995, 14, 177-185.

33 M. I. Alcalde, M. P. Gómez-Sal and P. Royo, Organometallics, 2001, 20, 4623-4631.

34 S. Ciruelos, T. Cuenca, R. Gómez, P. Gómez-Sal, A. Manzanero and P. Royo, Organometallics, 1996, 15, 5577-5585.

35 A. B. Vázquez, P. Royo and E. Herdtweck, J. Organomet. Chem., 2003, 683, 155-164.

36 L. Postigo, A. B. Vázquez, J. Sánchez-Nieves, P. Royo and E. Herdtweck, Organometallics, 2008, 27, 5588-5597.

37 G. Jiménez, P. Royo, T. Cuenca and M. Galakhov, Organometallics, $2001,20,5237-5240$.

38 A. D. Horton, J. de With, A. J. van der Linden and H. von der Weg, Organometallics, 1996, 15, 2672-2674.

39 J. T. Park, S. C. Yoon, B. J. Bae, W. S. Seo, I. H. Suh, T. K. Han and J. R. Park, Organometallics, 2000, 19, 1269-1276.

40 O. Buitrago, C. R. de Arellano, G. Jiménez and T. Cuenca, Organometallics, 2004, 23, 5873-5876.

$41 \mathrm{H}$. Braunschweig, F. M. Breitling, C. Burschka and F. Seeler, J. Organomet. Chem., 2006, 691, 702-710.

42 Y. Kim, G. K. Jnaneshwara and J. G. Verkade, Inorg. Chem., 2003, 42, $1437-1447$

43 P. Arndt, A. Spannenberg, W. Baumann, S. Becke and U. Rosenthal, Eur. J. Inorg. Chem., 2001, 2885-2890. 
44 S. Lancaster, Synthetic Pages, 2003, 215, http://www. syntheticpages.org.

45 S. G. Feng, G. R. Roof and E. Y. X. Chen, Organometallics, 2002, 21, 832-839.

46 S. Lancaster, in Synthetic Pages, 2003, 216, http://www. syntheticpages.org.

47 S. Y. Knjazhanski, G. Cadenas, M. Garcia, C. M. Perez, I. E. Nifant'ev, I. A. Kashulin, P. V. Ivchenko and K. A. Lyssenko, Organometallics, 2002, 21, 3094-3099.
48 G. H. Llinas, M. Mena, F. Palacios, P. Royo and R. Serrano, J. Organomet. Chem., 1988, 340, 37-40.

49 R. H. Blessing, Acta Crystallogr., 1995, 51, 33-38.

50 L. J. Farrugia, J. Appl. Crystallogr., Sect. A, 1999, 32, 837838.

51 G. M. Sheldrick, SHELXL-97, (1998) University of Gottingen, Gottingen.

52 P. v. d. Sluis and A. K. Spek, Acta Crystallogr., Sect. A: Found. Crystallogr., 1990, A46, 194-201. 